This item was submitted to Loughborough's Research Repository by the author.

Items in Figshare are protected by copyright, with all rights reserved, unless otherwise indicated.

\title{
What is a better cross-hedge for energy: Equities or other commodities?
}

PLEASE CITE THE PUBLISHED VERSION

https://doi.org/10.1016/j.gfj.2018.02.003

PUBLISHER

(c) Elsevier

VERSION

AM (Accepted Manuscript)

PUBLISHER STATEMENT

This paper was accepted for publication in the journal Global Finance Journal and the definitive published version is available at https://doi.org/10.1016/j.gfj.2018.02.003.

\section{LICENCE}

CC BY-NC-ND 4.0

\section{REPOSITORY RECORD}

Olson, Eric, Andrew Vivian, and Mark Wohar. 2019. "What Is a Better Cross-hedge for Energy: Equities or Other Commodities?". figshare. https://hdl.handle.net/2134/38155. 


\title{
What is a better cross-hedge for energy: Equities or other commodities?
}

\begin{abstract}
Can energy futures returns be effectively hedged? If so, what is the best hedge instrument?

We study the hedging performance of several cross-hedges including the equity market, oil and gas equities, precious metals, industrial metals, and agricultural commodities. Our main conclusion is that cross-hedging fluctuations in the energy market is generally not very effective and that any reduction in overall risk is small unless the oil and gas equity index is used. While all cross-hedges have performed better since 2007, the oil and gas equity index is the most effective, reducing risk by up to twenty percent, but it is also the most expensive.
\end{abstract}

JEL classifications:

C12

C32

G10

Keywords:

Dynamic hedging

Energy

Commodities

Equities

Out-of-sample 


\section{Introduction}

The connections among different parts of the financial system have interested academics and practitioners for decades. Recent work reports spillovers among energy, equities, and other commodities, documenting increasing correlations especially between energy and equity markets; studies also often estimate how costly the hedge is on average (Mensi, Beljid, Boubaker, \& Managi, 2013; Olson, Vivian, \& Wohar, 2014; Sadorsky, 2014). This would suggest that hedging across markets might be considered by an investor aiming to reduce the risk of an investment without sacrificing all of the return. However, to date there has been no extensive, real-time (out-of-sample) study on how effective cross-hedging is for the energy market. This paper fills this gap by examining cross-hedging via equities or other major commodity sectors, using multiple measures of risk (including downside risk) and alternative methods of estimating the hedge ratio, specifically ordinary least squares vs. generalized autoregressive conditional heteroskedasticity. This analysis provides insight into whether investors should seriously consider cross-hedging. If so, then the best hedging instrument can be identified; if not, the financial community should seek alternative risk management tools.

Energy prices in general and oil prices specifically have a long history of high volatility (Vivian \& Wohar, 2012). In two recent episodes, oil prices fell by more than $50 \%$ within a year (spring 2008-winter 2008 and summer 2014-spring 2015). While a substantial number of papers have examined the fundamentals behind the plunge in oil prices, Cornell (2015) and Areski and colleagues (2014) emphasize that oil prices can be viewed as a commodity as well as a financial asset. Such dramatic declines in energy prices would have substantial effects on energy investors (with a long position in energy) and energy producers. To manage their exposure to such risks, these stakeholders should consider appropriate ways to hedge; and they require solutions to be implemented before or during these bad times, so a purely in-sample 
analysis is insufficient to meet their needs.

Conventional hedging strategies using futures have been extensively studied in the academic as well as the practitioner literature, although less attention has been paid to crosshedging. Hedgers differ from portfolio investors in that they are more concerned with the risks they face than the returns they can obtain. Therefore, the objective of hedging is different from that of asset allocation strategies. Mean-variance portfolio investors attempt to obtain a trade-off between asset return and risk; the diversification benefit they get from including energy and other commodities has been studied in detail (among others, by Belousova \& Dorfleitner, 2012; Galvani \& Plourde, 2010). On the other hand, the objective of hedgers is to minimize their risk, leaving their return unmanaged, and this strategy has not been extensively investigated in a cross-hedging setting for energy, especially out of sample. Given the recent work documenting spillovers and rising correlations between energy and other assets (Mensi et al., 2013; Olson et al., 2014; Sadorsky, 2014), the prime focus of this paper is to assess in detail how effective cross-hedging actually is.

Several econometric approaches have been used to estimate the optimal hedge ratios, including ordinary least squares (OLS), vector autoregression (VAR), vector error correction (VEC) models, and generalized autoregressive conditional heteroskedasticity (GARCH) models. It is important to estimate time-varying hedge ratios because there is strong evidence that the key inputs into the hedge ratio, return variances and covariances, are themselves not constant (see, e.g., Figlewski, 1984; Herbst, Kare, \& Caples, 1989; Hill \& Schneeweis, 1982; Kroner \& Sultan, 1993).

We study the out-of-sample hedging performance of several cross-hedges for energy, including the equity market, the oil and gas equity index, precious metals, industrial metals, and agricultural commodities. We use data from the first week of 1985 until the end of July 2014, with the first five years of data used for model estimation and the real-time analysis 
beginning from the first week of 1990 . We examine the performance of two of the most commonly applied methods for obtaining hedge ratios, namely, OLS and multivariate GARCH (MGARCH), and estimate these in real time using a recursive approach that allows us to calculate time-varying hedge ratios. Further, while variance minimization is often taken as the main objective of the hedger, arguably downside risk minimization and loss mitigation can be just as important, if not more so (see for example Stulz, 1996). Therefore, in order to examine how effective hedging is in general, we consider not only the traditional hedging

effectiveness measure (Ederington, 1979) but also measures that are related to downside risk, including semivariance and total losses.

The rest of the paper proceeds as follows. Section 2 summarizes recent literature. Section 3 discusses our data and methods. Section 4 presents our model results and evaluates the time-varying conditional correlations and time-varying hedge ratios. Section 5 concludes.

\section{Literature review}

Johnson (1960) and Stein (1961) combine traditional hedging theory with profit maximization to introduce minimum-variance hedging. The minimum-variance hedging strategy consists of choosing a futures position to minimize the variance of the hedged portfolio and is, by definition, the best strategy according to in-sample hedging effectiveness comparisons (Kroner \& Sultan, 1993).

The optimal futures hedge ratio required to lower the risk associated with a spot position is usually determined with the minimum-variance approach (Brooks, Henry, \& Persand, 2002; Chen, Lee, \& Shrestha, 2003). The minimum-variance hedge ratio (MVHR) can be viewed as the slope coefficient from an OLS regression in which the (log) spot return is regressed on the $(\log )$ futures return.

Many scholars have applied econometric models to estimate optimal hedge ratios 
(OHR). For example, the question is asked whether a dynamic hedging strategy estimated using a GARCH model outperforms a minimum-variance hedging strategy estimated using OLS. The minimum-variance hedging strategy is often used as a benchmark against which practitioners and empirical researchers assess other investment strategies. Various studies have found that different models generate the "best" hedging performance. Baillie and Myers (1991), Park and Switzer (1995), Kavussanos and Nomikos (2000), and Floros and Vougas (2006) got superior performance by using a bivariate GARCH model. In contrast, Ghosh (1993) found better performance employing a VECH model (among constant hedge models), whereas Lien and colleagues (2002) and Moosa (2003) found that the OLS approach performed better than others.

Linear regression models, such as OLS, are based on the assumption that the relationship between spot and future prices does not change over time (Ederington, 1979). However, the distributions of many asset returns are time-varying, and thus the covariance matrix of the asset returns changes over time (Figlewski, 1984; Herbst et al., 1989; Hill \& Schneeweis, 1982). To improve hedging performance, the use of time-varying hedge ratios has been suggested, which Kroner and Sultan (1992) argue is more realistic than expecting the optimal ratio to be constant.

GARCH methods (Engle, 1982) have been used to estimate time-varying hedge ratios in several recent studies (e.g., Baillie \& Myers, 1991; Bhaduri \& Durai, 2008; Choudhry, 2004; Floros \& Vougas, 2006; Holmes, 1995; Kavussanos \& Nomikos, 2000; Lypny \& Powella, 1998; Park \& Switzer, 1995). By modelling the time-varying covariance, GARCHbased minimum-variance hedging should reduce the variance more than naive hedging. However, as a result of uncertainty in the GARCH specification and parameter uncertainty, this conclusion may not hold true in practice. Furthermore, hedge ratios obtained from GARCH-type models are often not stable and would in practice require frequent rebalancing. 
Park and Switzer (1995a, 1995b) use the MGARCH model to calculate hedges for three stock index futures, the S\&P 500, MMI futures, and the Toronto 35 index futures; they report that the bivariate GARCH model improves hedging performance. Lypny and Powella (1998) use a VEC-MGARCH $(1,1)$ model and also report that the GARCH model is better than a constant hedge model. However, Lien and colleagues (2002) and Moosa (2003) find the opposite: that using a basic OLS approach results in better hedging performance. Thus the best hedging model likely depends upon the market and time period chosen.

Haigh and Holt (2002) demonstrate that a bivariate GARCH model that accounts for volatility spillovers between spot and futures markets results in a better hedging strategy than a BGARCH model that ignores spillover effects. Alizadeh and colleagues (2008) find that the optimal hedge ratio from a Markov regime-switching BGARCH (RS-GARCH) model outperforms the naïve strategy and time-invariant optimal hedge ratios. Alexander, Prokopczuk, and Sumawong (2013) conduct an extensive out-of-sample study of minimumvariance hedging for a complex underlying position, the crack spread. They use several hedging approaches and covariance estimation techniques, which are compared with a simple naïve hedge, explicitly taking into account margin and transaction costs, which are not explicitly modelled in most previous work. Alexander and colleagues (2013), in contrast to other researchers, find that there is no econometric method that can outperform the naïve hedge.

Lien $(2005 \mathrm{a}, \mathrm{b})$ suggests that the conventional hedging strategy tends to outperform others in terms of out-of-sample hedging effectiveness, unless there is a structural break across the estimation sample. Lien and colleagues (2015) compare the OLS hedging strategy (i.e., the unconditional strategy) with other methods, using Ederington's hedging 
effectiveness measure (the EHE). ${ }^{1}$ They show that the OLS hedging strategy will tend to outperform the optimal conditional hedging strategy. This partly reflects the different objectives of the strategies, since OLS aims to minimize unconditional volatility, while approaches that account for time-varying volatility (e.g., GARCH) minimize conditional volatility. Similarly, if there is structural change, then GARCH may not perform well in terms of EHE.

Wang, Wu, and Yang (2015) investigate the out-of-sample performance of naïve hedging and analyze 24 different futures markets where the underlying assets include commodities, currencies, and stock indices. They employ 18 different models to estimate the parameters necessary to evaluate the hedges, and none of the 18 can significantly and consistently outperform the naïve strategy across the 24 futures markets examined, a finding that they support with a battery of robustness tests that change sample period, estimation window, and hedging horizon. They provide evidence that both estimation error and model misspecification contribute to the poor performance of the more complex models. This corroborates some portfolio allocation studies that suggest that both estimation error and model misspecification (DeMiguel, Garlappi, \& Uppal, 2009; Tu \& Zhou, 2011) are important.

A relatively small literature introduced by Anderson and Danthine (1981)examines the effectiveness of cross-hedges, which is the focus of this paper. Olson and colleagues (2015) evaluate

\footnotetext{
${ }^{1}$ Ederington (1979) proposed to measure the effectiveness of a futures hedging
} strategy by the percentage drop in variance of the hedged portfolio relative to that of the spot position; the strategy having the greatest EHE is deemed the best. The EHE measure is termed the certainty equivalent and is taken by comparing changes in expected utility from the hedged and unhedged portfolios. 
whether hedging with commodities can reduce the risk of an (unhedged) equity index portfolio. They employ three different methods to generate time-varying hedge ratios: realized variances and covariance, GARCH (BEKK), and OLS. They examine these timevarying hedge ratios and how much their implementation can reduce portfolio risk in real time relative to a long position in the S\&P 500. While some previous work estimates average hedge ratios between commodities and an equity index (e.g., Mensi et al., 2013; Sadorsky, 2014), Olson and colleagues extend this to examine directly how much risk can be reduced by implementing such strategies out-of-sample. They additionally investigate whether the effectiveness of the hedges varies over time. Their results are as follows. First, commodities generally do not hedge the S\&P 500 very well, especially during the financial crisis. Second, contrary to Tang and Xiong (2012), the correlation between the S\&P 500 and commodities is generally low, which may help explain why commodities are of little use as a hedging instrument.

\section{Data and methods}

Our data, taken from Thomson's Datastream, are weekly for January 1, 1985, to July 31, 2014. Because we undertake historical portfolio performance analysis below, we chose to estimate the models recursively so as to rid the correlations of any "look ahead bias." That is, in order to obtain the hedge ratios for the second week of 1990, we use the data spanning the first week of 1985 through the first week of 1990. In order to obtain the hedge ratio for the third week of 1990, we subsequently add an additional week of data and re-estimate our models, and so on until the end of our sample period.

We use excess return indices from Goldman Sachs: the energy index, the industrial metals index, the precious metals index, the agriculture index, and the livestock index, which is based on a long-only position in a specific commodity future where each index component 
is capitalization weighted. Each index is intended to serve as a barometer for the whole of its sector, and they are frequently used as benchmarks for investment performance. We use the S\&P 500 spot index return to proxy U.S. equity markets, and the Datastream U.S. oil and gas equity index to proxy the performance of U.S. energy companies. To calculate the various hedge ratios we employ two methods: multivariate GARCH and recursive OLS.

\subsection{The multivariate GARCH model}

We estimate the GARCH (BEKK) model with the mean equations specified as follows:

$$
Y_{t}=C+A Y_{t-1}+V_{t}
$$

where $\mathbf{Y}_{\mathbf{t}}=\left(\mathrm{R}_{\mathrm{t}}^{i}, \mathrm{R}_{\mathrm{t}}^{\text {Energy }}\right)^{\prime} . \mathrm{R}_{\mathrm{t}}^{i}$ is the weekly return of a specific commodity index or S\&P 500 index, and $\mathrm{R}_{\mathrm{t}}^{\text {Energy }}$ is the weekly return on the energy index. $\mathbf{A}$ and $\mathbf{C}$ are $n \times n$ matrices of coefficients, and $\mathbf{V}_{\mathrm{t}}=\left(\varepsilon_{\mathrm{t}}^{\mathrm{i}}, \varepsilon_{\mathrm{t}}^{\text {Energy }}\right)^{\prime}$ is a vector containing the residuals in (1). Each residual,

$$
\varepsilon_{\mathrm{t}}=\mathrm{h}_{\mathrm{t}}^{\frac{1}{2}} \eta_{\mathrm{t}}
$$

and each innovation $\eta_{i, t}$ is an independent and identically distributed (i.i.d.) random shock.

We use the BEKK from Engle and Kroner (1995) to model the conditional second moments:

$$
\mathbf{H}(\mathrm{t})=\mathbf{C}^{\prime} \mathbf{C}+\mathbf{A}^{\prime} \mathbf{u}(\mathrm{t}-1) \mathbf{u}^{\prime}(\mathrm{t}-1) \mathbf{A}+\mathbf{B}^{\prime} \mathbf{H}(\mathrm{t}-1) \mathbf{B} .
$$

$\mathbf{A}$ and $\mathbf{B}$ are general $n \times n$ matrices, and $\mathbf{C}$ and $\mathbf{D}$ are lower triangular matrices resulting in each term being positive semidefinite. From (3) the conditional variance for the energy and other index returns is determined by past shocks and past conditional variances of the energy return and the other commodity or S\&P 500 index. To calculate the hedge ratio we follow Kroner and Sultan (1993) and Mensi and colleagues (2013) and use the estimated conditional covariances. The interpretation of the hedge ratio would be that in order to minimize the risk of being long $\$ 1$ of the energy index, the investor would need to short $\beta_{t}$ dollars of the commodity indices. That is, 


$$
\beta_{\mathrm{t}}^{\text {commodity,Energy }}=\frac{\mathrm{h}_{\mathrm{t}}^{\text {commodity,Energy }}}{\mathrm{h}_{\mathrm{t}}^{\text {commodity }}} .
$$

\subsection{Recursive $O L S$}

We also calculated hedge ratios by recursively estimating OLS regressions. Thus we estimated

$$
\text { Energy_Ret }_{t}=\beta_{\mathrm{t}} \operatorname{Ret}_{i, t}+\varepsilon_{\mathrm{t}} \text {, }
$$

where Energy_Ret is the return of the energy index in period $t$, and $\operatorname{Ret}_{i, t}$ is the return of commodity $i$ or the S\&P 500 in period t. Given the definition of the hedge ratio above, $\beta_{\mathrm{t}}$ is the estimated hedge ratio over the respective sample period. We estimated (5) recursively so as to allow the hedge ratio to vary over time. ${ }^{2}$

\subsection{Hedge effectiveness, risk, and performance metrics}

To assess the performance of the hedges we consider the performance of a hedged portfolio $\left(P_{H}\right)$ compared to an unhedged portfolio $\left(P_{\mathrm{U}}\right) . P_{\mathrm{U}}$ simply has a portfolio weight of 1 in the energy index; this portfolio earns a return of $\mathrm{R}_{\mathrm{U}} . P_{H}$ is a portfolio with a weight of 1 in the energy index and a weight of $-\mathrm{H}$ in the commodity or equity hedging instrument, where $\mathrm{H}$ is the hedge ratio; $P_{H}$, the hedged portfolio, earns a return of $\mathrm{R}_{H}$.

As we note above, hedge effectiveness tells us what proportion of the portfolio variance is reduced by taking the estimated position in the hedge, and is calculated as

$$
\frac{\sum_{t=1}^{T}\left(R_{U, t}-\bar{R}_{U}\right)^{2}-\sum_{t=1}^{T}\left(R_{H, t}-\bar{R}_{H}\right)^{2}}{\sum_{t=1}^{T}\left(R_{U, t}-\bar{R}_{U}\right)^{2}} .
$$

A number greater than zero indicates that the hedge has reduced the overall variance of the portfolio. For example, a value of 0.15 would suggest that taking a position in the hedge has

\footnotetext{
${ }^{2}$ We did estimate rolling OLS hedges as well, which performed in a way qualitatively similar to the recursive hedge.
} 
reduced the variance of the portfolio by $15 \%$ compared to the portfolio excluding the hedge.

We also consider two measures of downside risk. The semivariance measure is defined as

$$
\frac{\sum_{t=1}^{T}\left(R_{U, t}^{B M}-\bar{R}_{U}\right)^{2}-\sum_{t=1}^{T}\left(R_{H, t}^{B M}-\bar{R}_{H}\right)^{2}}{\sum_{t=1}^{T}\left(R_{U, t}^{B M}-\bar{R}_{U}\right)^{2}} .
$$

Here $R^{B M}$ is equal to $\mathrm{R}$ if the return is not greater than the sample mean and equal to the sample mean otherwise. Positive values of the semivariance measure suggest that the hedge has reduced the variance of the portfolio on the downside.

The second measure of downside risk is simply the sum of losses. Define $R^{-}$as equal to the $\mathrm{R}$ when the return is less than 0 and 0 otherwise. The sum of losses measure is then defined as

$$
\frac{\sum_{t=1}^{T} R_{U, t}^{-}-\sum_{t=1}^{T} R_{H, t}^{-}}{\sum_{t=1}^{T} R_{U, t}^{-}} .
$$

We finally consider two measures of portfolio performance. The increase in annualized portfolio return is defined as

$$
52\left(\sum_{t=1}^{T} R_{H, t}-\sum_{t=1}^{T} R_{U, t}\right)
$$

This measures the increase in the portfolio return, annualized by multiplying the weekly figures by 52 . For example, a value of -0.11 indicates that taking a position in the hedge reduces the return of the portfolio by $1 \%$ compared to the unhedged portfolio.

Finally we consider the sum of gains. Define $R^{+}$as equal to the $\mathrm{R}$ when the return is greater than 0 and 0 otherwise. The sum of gains measure is then defined as

$$
\frac{\sum_{t=1}^{T} R_{H, t}^{+}-\sum_{t=1}^{T} R_{U, t}^{+}}{\sum_{t=1}^{T} R_{U, t}^{+}} .
$$

This sum simply indicates whether the hedged portfolio results in higher cumulative returns 
than the unhedged portfolio.

\section{Descriptive statistics and hedge ratios}

Panel A in Table 1 displays the descriptive statistics of the constructed returns for the commodities used in our sample period; Panel B of Table 1 displays the correlation matrix of the constructed returns; and Panel C displays the sample statistics of the hedge ratios calculated from the two methods discussed above. Not surprisingly, Panel A of Table 1 shows that the weekly return of the commodities is relatively small. However, the standard deviation of the energy index is approximately twice as large as that of the S\&P 500 and the other commodities in our sample. Panel B of Table 1 shows the variations in the first and second moments of the hedge ratios. For instance, for every commodity, using the recursive OLS method results in substantially lower standard deviations of the hedge ratio than using the multivariate GARCH model. Recursive OLS hedge ratios are more stable, given how much smaller the range of the series is.

Figure 1 displays the hedge ratios calculated from our above two methods. The gray (or lighter) line displays the hedge ratios calculated using the recursive multivariate GARCH model, and the black (or darker) line displays the results from using the recursive OLS method. Note that the hedge ratios calculated using the multivariate GARCH model are, not surprisingly, much more variable than those calculated using the recursive OLS estimates.

From Figure 1 it is clear that after 2008 the multivariate GARCH hedging ratios for all commodities are much more persistent than before 2008. Before 2008 the GARCH hedge forecasts cross the $\mathrm{X}$ axis at regular intervals, but since 2008 they have been above 0 for almost the whole period. Since 2008, the OLS hedge ratios have been generally higher than they were in the earlier period for the S\&P 500, industrial metals, and agriculture, but about the same for precious metals and oil and gas equities. It is clear that the GARCH hedge ratios are much more variable than OLS hedge ratios. However, it remains to be seen whether the 
GARCH hedge ratios are picking up random instantaneous movements in the parameters of interest or whether they are actually responding to fluctuations that will appear over the next week or even longer. The results from our tests will shed light on this.

\section{Hedge portfolio effectiveness and performance}

Can energy futures returns be effectively hedged? If so, what is the best hedging instrument? In this section we study the hedge performance of several cross-hedges including the equity market, precious metals, industrial metals, and agricultural commodities. In our tests we form a portfolio with a weight of $100 \%$ in energy that is short $\mathrm{H} \%$ in the commodity, where $\mathrm{H}$ is the hedge ratio, and compare these results to a benchmark that is simply long $100 \%$ in the equity index. This approach differs from that used in studies examining diversification, where a long position (positive weight) in the commodity is taken. It also differs from that used by Wang and colleagues (2015), who examine whether estimated (standard) hedges can outperform a naive hedge. We examine three well-established measures of risk: variance, semivariance, and cumulative losses. Finally we also consider the impact of the hedge on portfolio returns, measured by mean return and cumulative gains.

Table 2 summarizes results for the full-sample period for hedging the energy index. The first cross-hedge we examine is the S\&P 500 index, using hedge ratios calculated via GARCH and OLS methods. The results suggest that, at best, a modest amount of risk can be reduced by hedging with the S\&P 500, and for OLS methods there is virtually no risk reduction at all. The oil and gas equity index cross-hedge is able to hedge a large amount of risk when we use either estimation method, with the risk reduction measures at $21.7 \%$ for GARCH and $23.0 \%$ for OLS. For industrial metals a modest amount of risk can be reduced by either the GARCH or OLS hedge ratio, although again the GARCH hedge ratio performs better. Precious metals can hedge a very modest amount of risk under either estimation method, although for GARCH the precious metals hedge doesn't perform as well as the 
industrial metals hedge. The agriculture index cross-hedge hedges only a small amount of risk, and none of the risk reduction measures are above $5.4 \%$. The livestock index performs the worst out of all the possible cross-hedges. None of the risk measures provide more than a $1.42 \%$ reduction, and some even have a negative value, indicating that they actually increase risk.

The oil and gas equity index reduces mean return by 5.7\% for the GARCH estimates and $6.6 \%$ for the OLS estimates. The other cross-hedges make more modest reductions in the mean return, and some increase it slightly. While in almost all cases the sum of the gains is lower, the change is almost fully offset by the lower cumulative losses; hence the very small net effect on the mean return. The key message from the full sample is that cross-hedging fluctuations in the energy market is generally not very effective, and that any reductions in risk overall are generally no more than $11 \%$. The exception is the oil and gas equity index, which may be an effective hedge but also a rather expensive one.

Table 3 provides subsample analyses for cross-hedges of the energy index in three periods of approximately equal length: 1990-1997, 1998-2005, and 2006-2014. Panel A, which reports results for 1990-1997, shows that the cross-hedge with the S\&P 500 index, as estimated with the GARCH method, is somewhat more effective for this subperiod than for the full sample, reducing up to $12.2 \%$ of risk. In contrast, the S\&P 500 hedge as estimated with OLS is not very effective at all, reducing less than $2 \%$ of risk. For the oil and gas equity index the reduction in risk is close to $10 \%$, less than it was for the full sample. None of the other cross-hedges reduce risk by more than $2.5 \%$ during $1990-1997$, and in some cases the so-called hedge actually increases risk (albeit slightly). In summary, while the S\&P hedge might have been moderately effective during 1990-1997, cross-hedging with other commodities would have been almost completely ineffective.

Panel B reports results for 1998-2005. The most effective hedge for this period is the 
oil and gas equity index, with risk reduction of about $12 \%$, close to what it was for 1990 1997. The results for the other commodities demonstrate that none of the commodities considered are effective hedges for the energy return during this period. With the exception of the oil and gas equity index, the maximum reduction in risk is less than $2.5 \%$, and again, in some cases the so-called hedge actually increases risk. In general the results suggest that practitioners wishing to reduce risk would have been well advised to look at alternatives to these cross-hedges.

Panel C covers 2006-2014. The results here differ markedly from those for the other two subperiods. A substantive portion of risk can be reduced through cross-hedging during this period. The oil and gas equity hedge can reduce risk by up to $43 \%$ if GARCH estimation is employed (based on the variance risk measure). The S\&P 500 hedge can reduce risk by 15 to $20 \%$ if GARCH estimation is employed (depending on whether one uses the variance or semivariance risk measure), but only minimal risk reduction is possible when the hedge is estimated using OLS. Industrial metals, precious metals, and agriculture can each hedge more than $10 \%$ of risk, a result that is robust across risk measures (variance vs. semivariance) and estimation methods (GARCH vs. OLS). One other hedge that reduces risk by a large amount during this period is industrial metals. This cross-hedge would have reduced risk by around $30 \%$ if one uses the GARCH estimation method. The livestock cross-hedge continues to perform poorly even during this most recent period, perhaps because livestock prices are driven more by idiosyncratic supply factors than by common demand factors.

So why have cross-hedges performed better since 2006? There are a couple of possible explanations. First, the financial markets upon which these instruments trade have seen trading volumes increase dramatically, and more speculative investors have been active in the markets. This has led to more common movements in commodity returns over recent years (see for example Ma, Vivian, \& Wohar, 2016). Second, the major global economic 
shocks following the financial crisis of 2007-2008 could also have led to greater comovement of these instruments. The potential policy implications of these two interpretations differ markedly. If the first is correct, it would suggest that cross-hedging could be useful in general for those wishing to reduce their exposure to energy returns in the future. If the second is correct, it would suggest that cross-hedging is useful only during major global shocks. To provide some preliminary evidence on the competing explanations, we plot the performance of the risk measures over time.

Figure 2, which plots the time variation in hedging effectiveness, suggests that before 2006 there were no upward trends in general, but only a couple of short-term upward spikes. However, from 2007 onwards there tends to be an upward movement in the ratios in general. Figure 3 plots the time variation in downside risk as measured by semivariance. It suggests that before 2000 there were no upward trends in general, only a couple of short-term upward spikes. However, even before the financial crisis there is the beginning of an upward trend for some ratios. There is a sudden sharp spike upwards during 2007-2009. After 2009, there may be a slight upward trend that persists upwards for most of the rest of the sample, but this is not as strong as that given by the hedging effectiveness measure (Figure 2). Figure 2 suggests that while the effectiveness of these cross-hedges was generally strongest during the financial crisis, there seem to be benefits that continued after this as well.

So why has this improvement continued? We believe that the continuing covariance between the instruments is likely due to a combination of (1) the uptick in the global business cycle after 2008, (2) the easy money policies of central banks between 2008 and 2014, and (3) the financialization of commodities, which increased the volume of trading in the underlying commodities. Moreover, the advent of commodity exchange traded funds (ETFs) has enabled retail investors to add commodities to their existing portfolios (especially oil and gold ETFs). Perhaps additional examination of the performance of these cross-hedges over 
the next few years could provide more conclusive evidence.

For robustness, instead of using the energy index, we also provide cross-hedges of WTI (Table 4, Panel A) as well as natural gas (Table 4, Panel B) over the 2006-2014 period; these are both based on the S\&P GSCI excess return series. Note in Panel A of Table 4 that the results for hedging WTI oil over the period 2006-2014 are similar to those in Panel C of Table 3. The S\&P 500 can reduce the variance by approximately $10 \%$ if GARCH is used. The oil \& gas equity index, regardless of whether GARCH or OLS is used, again reduces the variance of the portfolio by a large margin: $38 \%$. The GARCH estimates for industrial metals reduce the variance by $28.5 \%$, and the OLS estimates reduce the variance by $16.5 \%$. As in Panel C of Table 3, cross-hedging WTI oil (Table 4, Panel A) with precious metals and agriculture also reduces the variance of the portfolio, by $10.5 \%$ and $15 \%$, and $13 \%$ and $10.8 \%$, respectively. Overall, the results from hedging WTI are very similar to those from hedging the energy index. However, the results when we hedge natural gas (shown in Panel B of Table 4) are substantially different from the results of hedging the energy index and WTI. Note in Panel B of Table 4 that only the GARCH estimate from agriculture actually reduces the variance of the portfolio, by $10 \%$. In sum, our results strongly suggest that the energy index results are primarily capturing oil price changes.

\section{Conclusion}

To reiterate: the key message from the analysis of our full sample is that cross-hedging fluctuations in the energy market is generally not very effective unless one uses the oil and gas equity index — which can reduce risk by about $20 \%$ but also reduces return by $6 \%$ per annum. Since 2006 the cross-hedges we examine have performed better, with the oil and gas equity index reducing risk by about $40 \%$. We find similar results when we hedge WTI oil instead of the energy index over the recent period, but hedging natural gas is more difficult. The improved 
hedging performance over recent years may be due to more common movements in commodity returns, owing to the major global economic shocks of 2007-2008, increases in trading volume and increases in the number and activity of speculative investors.

Before 2006 any upward trends in the risk measures were generally small or moderate. However, from 2007 onwards there tends to be an upward movement in the ratios in general, in addition to the upward spike during 2007-2009. Thus, there is some evidence that in general the hedges have performed well over recent years, so investors could consider using them more broadly_especially the oil and gas equity index, which is the most effective hedge although the most expensive. Future researchers might examine the performance of these cross-hedges over the next few years to provide further evidence on whether crosshedges are effective only during crisis periods or whether they generally perform well in markets with substantial proportions of speculative investors. 


\section{References}

Alexander, C., Prokopczuk, M., \& Sumawong, A. (2013). The (de)merits of minimum-variance hedging: Application to crack spread. Energy Economics, 36, 698-707.

Alizadeh, A. H., \& Nomikos, N. K. (2004). A Markov regime switching approach for hedging stock indices. Journal of Futures Markets, 24, 649-674.

Alizadeh, A. H., Nomikos, N. K., \& Pouliasis, P. K. (2008). A Markov regime switching approach for hedging energy commodities. Journal of Banking \& Finance, 32, 1970-1983.

Anderson, R. W., \& Danthine, J. P. (1981). Cross hedging. Journal of Political Economy, 81, $1182-1196$.

Areski, R., Loungani, P., van der Ploeg, R., \& Venables, A. (2014). Understanding international commodity price fluctuations. Journal of International Money and Finance, 42, 1-8.

Baillie, R. T., \& Myers, R. J. (1991). Bivariate GARCH estimation of the optimal commodity futures hedge. Journal of Applied Econometrics, 6, 109-124.

Belousova, J., \& Dorfleitner, G. (2012). On the diversification benefits of commodities from the perspective of euro investors. Journal of Banking \& Finance, 36(9), 2455-2472.

Bhaduri, S. N., \& Durai, S. N. S. (2008). Optimal hedge ratio and hedging effectiveness of stock index futures: Evidence from India. Macroeconomics and Finance in Emerging Market Economies, 1, 121-134.

Brooks, C., Henry, O., \& Persand, G. (2002). The effect of asymmetries on optimal hedge ratios. Journal of Business, 75, 333-352.

Chang, C. Y., Lai, J. Y., \& Chuang, I. Y. (2010). Futures hedging effectiveness under the segmentation of bear/bull energy markets. Energy Economics, 32, 442-449.

Chen, S., Lee, C., \& Shrestha, K. (2003). Futures hedge ratios: A review. Quarterly Review of Economics and Finance, 43, 433-465.

Choudhry, T. (2004). The hedging effectiveness of constant and time-varying hedge ratios using three Pacific Basin stock futures. International Review of Economics and Finance, 13, 371- 
385.

Cornell, B. (2015). Invited editorial: Information arrival and the oil price collapse. Journal of Portfolio Management, 42(1), 1-4.

DeMiguel, V., Garlappi, L., \& Uppal, R. (2009). Optimal versus naïve diversification: How inefficient is the 1/N portfolio strategy? Review of Financial Studies, 22, 1915-1953.

Ederington, L. H. (1979). The hedging performance of the new futures markets. Journal of Finance, 34, 157-170.

Engle, R. F. (1982). Autoregressive conditional heteroskedasticity with estimates of the variance of United Kingdom inflation. Econometrica, 50, 987-1007.

Engle, R. F., \& Kroner, K. F. (1995). Multivariate simultaneous generalized ARCH. Econometric Theory, 11, 122-150.

Fama, E. F. (1965). The behavior of stock prices. Journal of Business, 38, 34-105.

Figlewski, S. (1984). Hedging performance and basis risk in stock index futures. Journal of Finance, 39(3), 657-669.

Floros, C., \& Vougas, D. V. (2006). Hedging effectiveness in Greek stock index futures market 1999-2001. International Research Journal of Finance and Economics, 5, 7-18.

Galvani, V., \& Plourde, A. (2010). Portfolio diversification in energy markets. Energy Economics, 32(2), 257-268.

Ghosh, A., 1993. Cointegration and error correction models: Intertemporal causality between index and futures prices. Journal of Futures Markets, 13, 193-198.

Haigh, M. S., \& Holt, M. T. (2002). Crack spread hedging: Accounting for time varying volatility spillovers in the energy futures markets. Journal of Applied Econometrics, 17, 269-289.

Herbst, A. F., Kare, D. D., \& Caples, S. C. (1989). Hedging effectiveness and minimum risk hedge ratios in the presence of autocorrelation: Foreign currency futures. Journal of Futures Markets, 9(3), 185-197.

Hill, J., \& Schneeweis, T. (1982). The hedging effectiveness of foreign currency futures. Journal 
of Financial Research, 5, 95-104.

Holmes, P. (1995). Ex ante hedge ratios and the hedging effectiveness of the FTSE-100 stock index futures contract. Applied Economics Letters, 2, 56-59.

Johnson, L. L. (1960). The theory of hedging and speculation in commodity futures. Review of Economic Studies, 27(3), 139-151.

Kavussanos, M. G., \& Nomikos, N. K. (2000). Constant vs. time varying hedge ratios and hedging efficiency in the BIFFEX market. Transportation Research Part E: Logistics and Transportation Review, 36, 229-248.

Kroner, K. F., \& Sultan, J. (1993). Time-varying distributions and dynamic hedging with foreign currency futures. Journal of Financial and Quantitative Analysis, 28, 535-551.

Lee, H.-T., Yoder, J. K., Mittelhammer, R. C., \& McCluskey, J. J. (2006). A random coefficient autoregressive Markov regime switching model for dynamic futures hedging. Journal of Futures Markets, 26(2), 103-129.

Lien, D. (2005a). A note on the superiority of the OLS hedge ratio. Journal of Futures Markets, $25,1121-1126$.

Lien, D. (2005b). The use and abuse of the hedging effectiveness measure. International Review of Financial Analysis, 14, 277-282.

Lien, D., Lee, G., Yang, L., \& Zhou, C. (2015). Evaluating the effectiveness of futures hedging. In Lee, C-F \& Lee J.C. Handbook of Financial Econometrics and Statistics (pp. 18911908). New York: Springer.

Lien, D., Tse, Y. K., \& Tsui, A. C. (2002). Evaluating the hedging performance of the constantcorrelation GARCH model. Applied Financial Econometrics, 12, 791-798.

Lypny, G., \& Powalla, M. (1998). The hedging effectiveness of DAX futures. European Journal of Finance, 4, 345-355.

Ma, J., Vivian, A., \& Wohar, W. (2016). What drives commodity returns? Country, sector or idiosyncratic factors? Working paper. 
Mandelbrot, B. (1963). The variation of certain speculative prices. Journal of Business, 36, 394 419.

Mensi, W., Beljid, M., Boubaker, A., \& Managi, S. (2013). Correlations and volatility spillovers across commodity and stock markets: Linking energies, food and gold. Economic Modelling, 32, 15-22.

Moosa, I. A. (2003). The sensitivity of the optimal hedging ratio to model specification. Finance Letters, 1, 15-20.

Olson, E., Vivian, A. J., \& Wohar, M. E. (2014). The relationship between energy and equity markets: Evidence from volatility impulse response functions. Energy Economics, 43, $297-$ 305.

Olson, E., Vivian, A. J., \& Wohar, M. E. (2015). Do commodities make effective hedges for equity investors? Working paper.

Park, T. H., \& Switzer, L. N. (1995a). Bivariate GARCH estimation of the optimal hedge ratios for stock index futures: A note. Journal of Futures Markets, 15, 61-67.

Park, T. H., \& Switzer, L. N. (1995b). Time-varying distributions and the optimal hedge ratios for stock index futures. Applied Financial Economics, 5, 131-137.

Rolfo, J. (1980). Optimal hedging under price and quantity uncertainty: The case of a cocoa producer. Journal of Political Economy, 88, 100-116.

Sadorsky, P. (2014). Modeling volatility and correlations between emerging market stock prices and the prices of copper, oil and wheat. Energy Economics, 43, 72-81.

Stein, J. L. (1961). The simultaneous determination of spot and futures prices. American Economic Review, 51, 1012-1025.

Stulz, R. (1996). Rethinking risk management. Journal of Applied Corporate Finance, 9, 8-25.

Tang, K., \& Xiong, W. (2012). Index investment and the financialization of commodities. Financial Analysts Journal, 68, 54-74.

Tu, J., \& Zhou, G. (2011). Markowitz meets Talmud: A combination of sophisticated and naïve 
diversification strategies. Journal of Financial Economics, 99, 204-215.

Wang, Y., Wu, C., \& Yang, L. (2015). Hedging with futures: Does anything beat the naïve hedging strategy? Management Science, 61(12), 2870-2889. 


\section{Table 1}

Descriptive statistics.

\begin{tabular}{|c|c|c|c|c|c|c|c|c|}
\hline \multicolumn{9}{|c|}{ Panel A: Sample statistics_-Returns } \\
\hline Variable & Nobs & Mean & SD & Min & Q1 & Med & Q3 & Max \\
\hline Energy & 1282 & 0.000 & 0.041 & -0.194 & -0.023 & 0.002 & 0.025 & 0.197 \\
\hline S\&P 500 & 1282 & 0.001 & 0.023 & -0.165 & -0.010 & 0.003 & 0.014 & 0.102 \\
\hline Oil \& gas equity & 1282 & 0.002 & 0.029 & -0.190 & -0.013 & 0.003 & 0.019 & 0.110 \\
\hline Industrial metals & 1282 & 0.000 & 0.028 & -0.133 & -0.016 & 0.000 & 0.017 & 0.147 \\
\hline Precious metals & 1282 & 0.000 & 0.024 & -0.138 & -0.011 & 0.000 & 0.013 & 0.118 \\
\hline Agriculture & 1282 & -0.001 & 0.026 & -0.132 & -0.016 & -0.001 & 0.013 & 0.115 \\
\hline Livestock & 1282 & -0.001 & 0.018 & -0.119 & -0.011 & 0.000 & 0.011 & 0.062 \\
\hline \multicolumn{9}{|c|}{ Panel B: Sample statistics-Hedge ratios with energy } \\
\hline Variable & Nobs & Mean & SD & Min & Q1 & Med & Q3 & Max \\
\hline \multicolumn{9}{|l|}{$\underline{S \& P} 500$} \\
\hline GARCH & 1282 & 0.077 & 0.548 & -3.412 & -0.178 & 0.116 & 0.407 & 1.208 \\
\hline OLS & 1282 & -0.098 & 0.145 & -0.347 & -0.219 & -0.105 & -0.005 & 0.171 \\
\hline \multicolumn{9}{|l|}{ Oil \& gas equity } \\
\hline GARCH & 1282 & 0.651 & 0.283 & -0.658 & 0.501 & 0.629 & 0.799 & 2.893 \\
\hline OLS & 1282 & 0.589 & 0.044 & 0.526 & 0.554 & 0.578 & 0.605 & 0.670 \\
\hline \multicolumn{9}{|l|}{ Industrial metals } \\
\hline GARCH & 1282 & 0.223 & 0.330 & -1.246 & 0.039 & 0.227 & 0.433 & 1.121 \\
\hline OLS & 1282 & 0.126 & 0.098 & 0.037 & 0.055 & 0.071 & 0.132 & 0.321 \\
\hline \multicolumn{9}{|l|}{ Precious metals } \\
\hline GARCH & 1282 & 0.245 & 0.064 & 0.090 & 0.191 & 0.210 & 0.293 & 0.372 \\
\hline OLS & 1282 & 0.406 & 0.054 & 0.319 & 0.355 & 0.402 & 0.440 & 0.532 \\
\hline \multicolumn{9}{|l|}{ Agriculture } \\
\hline GARCH & 1282 & 0.246 & 0.418 & -1.667 & -0.024 & 0.198 & 0.492 & 2.373 \\
\hline OLS & 1282 & 0.164 & 0.108 & 0.003 & 0.096 & 0.147 & 0.184 & 0.356 \\
\hline \multicolumn{9}{|l|}{$\underline{\text { Livestock }}$} \\
\hline GARCH & 1282 & 0.125 & 0.406 & -2.125 & -0.092 & 0.100 & 0.300 & 2.159 \\
\hline OLS & 1282 & 0.095 & 0.066 & -0.010 & 0.043 & 0.069 & 0.120 & 0.216 \\
\hline
\end{tabular}


Table 2

Hedge ratio results - full sample.

\begin{tabular}{lllllll}
\hline & \multicolumn{3}{c}{ Risk measures } & \multicolumn{2}{c}{ Return measures } \\
\hline Variable & Nobs & Variance & $\begin{array}{l}\text { Semi- } \\
\text { variance }\end{array}$ & $\begin{array}{l}\text { Sum of } \\
\text { losses }\end{array}$ & Mean & $\begin{array}{l}\text { Sum of } \\
\text { gains }\end{array}$ \\
\hline$\underline{\text { Unhedged }}$ & 1281 & 0.002 & 0.001 & -19.563 & 0.000 & 19.969
\end{tabular}

\begin{tabular}{lcclcc}
\hline $\begin{array}{l}\text { Improvement } \\
\text { relative To } \\
\text { benchmark (\%) }\end{array}$ & Variance & $\begin{array}{l}\text { Semi- } \\
\text { variance }\end{array}$ & $\begin{array}{l}\text { Sum of } \\
\text { losses }\end{array}$ & Mean & $\begin{array}{l}\text { Sum of } \\
\text { gains }\end{array}$ \\
\hline S\&P 500 & & & & 0.002 & -0.023 \\
\hline $\begin{array}{l}\text { GARCH } \\
\text { OLS }\end{array}$ & 0.078 & 0.107 & 0.026 & 0.007 & 0.003 \\
Oil \& gas equity & 0.008 & 0.011 & 0.007 & & \\
GARCH & 0.217 & 0.255 & 0.096 & -0.057 & -0.164 \\
OLS & 0.230 & 0.254 & 0.089 & -0.066 & -0.169 \\
Industrial metals & & & & & \\
GARCH & 0.090 & 0.099 & 0.045 & 0.002 & -0.041 \\
OLS & 0.063 & 0.070 & 0.029 & -0.003 & -0.033 \\
Precious metals & & & & & \\
GARCH & 0.052 & 0.053 & 0.010 & -0.023 & -0.038 \\
OLS & 0.065 & 0.065 & 0.027 & -0.006 & -0.033 \\
Agriculture & & & & & \\
GARCH & 0.040 & 0.048 & 0.032 & 0.023 & -0.004 \\
OLS & 0.049 & 0.054 & 0.026 & 0.009 & -0.015 \\
$\underline{\text { Livestock }}$ & & & & & \\
GARCH & -0.013 & -0.008 & -0.006 & 0.006 & 0.014 \\
OLS & 0.009 & 0.014 & 0.007 & 0.003 & -0.003 \\
& & & & & \\
\hline
\end{tabular}

Notes: This table reports the relative improvement of using a hedged portfolio compared to the benchmark of an unhedged portfolio. The unhedged portfolio has a weight of 1 in the energy index. The hedged portfolio has a weight of 1 in the energy index and a weight of $-\mathrm{H}$ in the other asset, where $\mathrm{H}$ is the hedge ratio. The sum of losses measure simply cumulates all the negative returns earned by each portfolio and reports the improvement from the hedged position, while the sum of gains cumulates all positive returns earned by each portfolio. Each measure is defined precisely in section 3 . 
Table 3

Hedge ratio results-subsample.

\begin{tabular}{|c|c|c|c|c|c|c|}
\hline \multicolumn{7}{|c|}{ Panel A: Early subsample (1990-1997) } \\
\hline & \multicolumn{4}{|c|}{ Risk measures } & \multicolumn{2}{|c|}{ Return measures } \\
\hline Variable & Nobs & Variance & $\begin{array}{l}\text { Semi- } \\
\text { variance }\end{array}$ & $\begin{array}{l}\text { Sum of } \\
\text { losses }\end{array}$ & Mean & $\begin{array}{l}\text { Sum of } \\
\text { gains }\end{array}$ \\
\hline$\frac{\text { Unhedged }}{\underline{\text { benchmark }}}$ & 416 & 0.002 & 0.001 & -5.761 & -0.000 & 14.701 \\
\hline $\begin{array}{l}\text { Improvement } \\
\text { relative to } \\
\text { benchmark }(\%)\end{array}$ & & Variance & $\begin{array}{l}\text { Semi- } \\
\text { variance }\end{array}$ & $\begin{array}{l}\text { Sum of } \\
\text { losses }\end{array}$ & Mean & $\begin{array}{l}\text { Sum of } \\
\text { gains }\end{array}$ \\
\hline \multicolumn{7}{|l|}{ S\&P 500} \\
\hline$\overline{\mathrm{GARCH}}$ & & 0.122 & 0.121 & 0.019 & 0.004 & -0.014 \\
\hline OLS & & 0.011 & 0.018 & 0.013 & 0.000 & 0.036 \\
\hline \multicolumn{7}{|l|}{ Oil \& gas equity } \\
\hline GARCH & & 0.083 & 0.135 & 0.017 & -0.077 & -0.123 \\
\hline OLS & & 0.100 & 0.123 & 0.020 & -0.075 & -0.123 \\
\hline \multicolumn{7}{|l|}{ Industrial metals } \\
\hline GARCH & & -0.028 & -0.038 & -0.024 & 0.001 & 0.026 \\
\hline OLS & & -0.006 & -0.007 & -0.003 & -0.002 & 0.001 \\
\hline \multicolumn{7}{|l|}{$\underline{\text { Precious metals }}$} \\
\hline GARCH & & 0.053 & 0.067 & 0.038 & 0.040 & 0.017 \\
\hline OLS & & 0.024 & 0.022 & 0.021 & -0.001 & 0.026 \\
\hline \multicolumn{7}{|l|}{ Agriculture } \\
\hline GARCH & & -0.028 & -0.021 & -0.020 & -0.005 & 0.012 \\
\hline OLS & & 0.000 & 0.001 & 0.001 & 0.000 & 0.003 \\
\hline \multicolumn{7}{|l|}{ Livestock } \\
\hline GARCH & & -0.014 & -0.066 & -0.020 & -0.001 & 0.007 \\
\hline OLS & & -0.002 & -0.001 & 0.001 & 0.001 & -0.002 \\
\hline
\end{tabular}

Notes: This table reports the relative improvement of using a hedged portfolio compared to the benchmark of an unhedged portfolio. The unhedged portfolio has a weight of 1 in the energy index. The hedged portfolio has a weight of 1 in the energy index and a weight of $-\mathrm{H}$ in the other asset, where $\mathrm{H}$ is the hedge ratio. The sum of losses measure simply cumulates all the negative returns earned by each portfolio and reports the improvement from the hedged position, while the sum of gains cumulates all positive returns earned by each portfolio. Each measure is defined precisely in section 3 . 


\begin{tabular}{|c|c|c|c|c|c|c|}
\hline \multicolumn{7}{|c|}{ Panel B: Mid subsample (1998-2005) } \\
\hline & \multicolumn{4}{|c|}{ Risk measures } & \multicolumn{2}{|c|}{ Return measures } \\
\hline Variable & Nobs & Variance & $\begin{array}{l}\text { Semi- } \\
\text { variance }\end{array}$ & $\begin{array}{l}\text { Sum of } \\
\text { losses }\end{array}$ & Mean & $\begin{array}{l}\text { Sum of } \\
\text { gains }\end{array}$ \\
\hline$\frac{\text { Unhedged }}{\text { benchmark }}$ & 417 & 0.002 & 0.001 & -6.611 & 0.003 & 7.676 \\
\hline $\begin{array}{l}\text { Improvement } \\
\text { relative to } \\
\text { benchmark }(\%)\end{array}$ & & Variance & $\begin{array}{l}\text { Semi- } \\
\text { variance }\end{array}$ & $\begin{array}{l}\text { Sum of } \\
\text { losses }\end{array}$ & Mean & $\begin{array}{l}\text { Sum of } \\
\text { gains }\end{array}$ \\
\hline$\underline{\text { S\&P } 500}$ & & & & & & \\
\hline $\begin{array}{l}\text { GARCH } \\
\text { OLS }\end{array}$ & & $\begin{array}{l}-0.030 \\
-0.008\end{array}$ & $\begin{array}{l}-0.022 \\
-0.001\end{array}$ & $\begin{array}{l}0.015 \\
0.002\end{array}$ & $\begin{array}{l}0.047 \\
0.006\end{array}$ & $\begin{array}{l}0.036 \\
0.004\end{array}$ \\
\hline $\begin{array}{l}\text { Oil \& gas equity } \\
\text { GARCH } \\
\text { OLS }\end{array}$ & & $\begin{array}{l}0.118 \\
0.148\end{array}$ & $\begin{array}{l}0.094 \\
0.118\end{array}$ & $\begin{array}{l}0.049 \\
0.046\end{array}$ & $\begin{array}{l}-0.030 \\
-0.060\end{array}$ & $\begin{array}{l}-0.074 \\
-0.103\end{array}$ \\
\hline $\begin{array}{l}\text { Industrial metals } \\
\text { GARCH } \\
\text { OLS }\end{array}$ & & $\begin{array}{r}-0.027 \\
0.009\end{array}$ & $\begin{array}{l}-0.018 \\
0.007\end{array}$ & $\begin{array}{l}0.001 \\
0.002\end{array}$ & $\begin{array}{l}0.004 \\
0.000\end{array}$ & $\begin{array}{l}0.004 \\
-0.008\end{array}$ \\
\hline $\begin{array}{l}\text { Precious metals } \\
\text { GARCH } \\
\text { OLS }\end{array}$ & & $\begin{array}{r}-0.018 \\
0.012\end{array}$ & $\begin{array}{l}0.003 \\
0.023\end{array}$ & $\begin{array}{l}-0.009 \\
0.005\end{array}$ & $\begin{array}{l}-0.010 \\
-0.002\end{array}$ & $\begin{array}{l}-0.003 \\
0.020\end{array}$ \\
\hline $\begin{array}{l}\text { Agriculture } \\
\text { GARCH } \\
\text { OLS }\end{array}$ & & $\begin{array}{r}-0.017 \\
0.015\end{array}$ & $\begin{array}{l}-0.022 \\
0.015\end{array}$ & $\begin{array}{l}0.034 \\
0.021\end{array}$ & $\begin{array}{l}0.049 \\
0.018\end{array}$ & $\begin{array}{l}0.022 \\
0.001\end{array}$ \\
\hline $\begin{array}{l}\text { Livestock } \\
\text { GARCH } \\
\text { OLS }\end{array}$ & & $\begin{array}{r}-0.054 \\
0.004\end{array}$ & $\begin{array}{l}-0.055 \\
0.005\end{array}$ & $\begin{array}{l}-0.018 \\
0.003\end{array}$ & $\begin{array}{l}0.002 \\
0.001\end{array}$ & $\begin{array}{l}0.018 \\
-0.002\end{array}$ \\
\hline
\end{tabular}

Notes: This table reports the relative improvement of using a hedged portfolio compared to the benchmark of an unhedged portfolio. The unhedged portfolio has a weight of 1 in the energy index. The hedged portfolio has a weight of 1 in the energy index and a weight of $-\mathrm{H}$ in the other asset, where $\mathrm{H}$ is the hedge ratio. The sum of losses measure simply cumulates all the negative returns earned by each portfolio and reports the improvement from the hedged position, while the sum of gains cumulates all positive returns earned by each portfolio. Each measure is defined precisely in section 3 . 


\begin{tabular}{|c|c|c|c|c|c|c|}
\hline \multicolumn{7}{|c|}{ Panel C: Latest subsample (2006-2014) } \\
\hline \multirow[b]{2}{*}{ Variable } & \multicolumn{3}{|c|}{ Risk measures } & \multicolumn{3}{|c|}{$\begin{array}{l}\text { Return } \\
\text { measures }\end{array}$} \\
\hline & $\begin{array}{l}\text { Nob } \\
\mathrm{s} \\
\end{array}$ & $\begin{array}{l}\text { Varianc } \\
\mathrm{e}\end{array}$ & $\begin{array}{l}\text { Semi- } \\
\text { variance }\end{array}$ & $\begin{array}{l}\text { Sum of } \\
\text { losses }\end{array}$ & Mean & $\begin{array}{l}\text { Sum of } \\
\text { gains }\end{array}$ \\
\hline$\frac{\text { Unhedged }}{\text { benchmark }}$ & 448 & 0.002 & 0.001 & -7.150 & -0.001 & 6.532 \\
\hline \multicolumn{2}{|l|}{$\begin{array}{l}\text { Improvement } \\
\text { relative to } \\
\text { benchmark }(\%)\end{array}$} & $\begin{array}{l}\text { Varianc } \\
\mathrm{e}\end{array}$ & $\begin{array}{l}\text { Semi- } \\
\text { variance }\end{array}$ & $\begin{array}{l}\text { Sum of } \\
\text { losses }\end{array}$ & Mean & $\begin{array}{l}\text { Sum of } \\
\text { gains }\end{array}$ \\
\hline \multicolumn{7}{|l|}{$\underline{S \& P} 500$} \\
\hline$\overline{\mathrm{GARCH}}$ & & 0.152 & 0.212 & 0.042 & -0.041 & -0.100 \\
\hline OLS & & 0.020 & 0.018 & 0.006 & -0.017 & -0.028 \\
\hline \multicolumn{7}{|l|}{ Oil \& gas equity } \\
\hline$\overline{\mathrm{GARCH}}$ & & 0.429 & 0.487 & 0.204 & -0.064 & -0.306 \\
\hline OLS & & 0.419 & 0.473 & 0.185 & -0.062 & -0.283 \\
\hline \multicolumn{7}{|l|}{ Industrial metals } \\
\hline GARCH & & 0.304 & 0.310 & 0.141 & 0.004 & -0.149 \\
\hline OLS & & 0.176 & 0.185 & 0.082 & 0.001 & -0.091 \\
\hline \multicolumn{7}{|l|}{ Precious metals } \\
\hline$\overline{\mathrm{GARCH}}$ & & 0.125 & 0.092 & 0.005 & -0.093 & -0.127 \\
\hline OLS & & 0.151 & 0.137 & 0.052 & -0.003 & -0.098 \\
\hline \multicolumn{7}{|l|}{ Agriculture } \\
\hline$\overline{\mathrm{GARCH}}$ & & 0.155 & 0.165 & 0.073 & 0.024 & -0.047 \\
\hline OLS & & 0.125 & 0.130 & 0.051 & 0.006 & -0.048 \\
\hline \multicolumn{7}{|l|}{ Livestock } \\
\hline$\overline{\mathrm{GARCH}}$ & & 0.026 & 0.080 & 0.016 & 0.025 & 0.015 \\
\hline OLS & & 0.022 & 0.034 & 0.015 & 0.007 & -0.007 \\
\hline
\end{tabular}

Notes: This table reports the relative improvement of using a hedged portfolio compared to the benchmark of an unhedged portfolio. The unhedged portfolio has a weight of 1 in the energy index. The hedged portfolio has a weight of 1 in the energy index and a weight of $-\mathrm{H}$ in the other asset, where $\mathrm{H}$ is the hedge ratio. The sum of losses measure simply cumulates all the negative returns earned by each portfolio and reports the improvement from the hedged position, while the sum of gains cumulates all positive returns earned by each portfolio. Each measure is defined precisely in section 3 . 


\section{Table 4}

Hedge ratio results - alternative benchmarks to be hedged - latest subsample.

\begin{tabular}{|c|c|c|c|c|c|c|}
\hline \multicolumn{7}{|c|}{ Panel A: Latest subsample WTI oil (2006-2014) } \\
\hline & \multicolumn{4}{|c|}{ Risk measures } & \multicolumn{2}{|c|}{$\begin{array}{l}\text { Return } \\
\text { measures }\end{array}$} \\
\hline Variable & $\begin{array}{l}\text { Nob } \\
\mathrm{s}\end{array}$ & $\begin{array}{l}\text { Varianc } \\
\text { e }\end{array}$ & $\begin{array}{l}\text { Semi- } \\
\text { variance }\end{array}$ & $\begin{array}{l}\text { Sum of } \\
\text { losses }\end{array}$ & Mean & $\begin{array}{l}\text { Sum of } \\
\text { gains }\end{array}$ \\
\hline$\frac{\text { Unhedged }}{\text { benchmark }}$ & 448 & 0.002 & 0.001 & -7.798 & -0.001 & 7.323 \\
\hline $\begin{array}{l}\text { Improvement } \\
\text { relative to } \\
\text { benchmark }(\%)\end{array}$ & & $\begin{array}{l}\text { Varianc } \\
\mathrm{e}\end{array}$ & $\begin{array}{l}\text { Semi- } \\
\text { variance }\end{array}$ & $\begin{array}{l}\text { Sum of } \\
\text { losses }\end{array}$ & Mean & $\begin{array}{l}\text { Sum of } \\
\text { gains }\end{array}$ \\
\hline$\underline{S \& P} 500$ & & & & & & \\
\hline $\begin{array}{l}\overline{\text { GARCH }} \\
\text { OLS }\end{array}$ & & $\begin{array}{l}0.106 \\
0.015\end{array}$ & $\begin{array}{l}0.163 \\
0.013\end{array}$ & $\begin{array}{l}0.028 \\
0.003\end{array}$ & $\begin{array}{l}-0.042 \\
-0.019\end{array}$ & $\begin{array}{l}-0.080 \\
-0.025\end{array}$ \\
\hline $\begin{array}{l}\text { Oil \& gas equity } \\
\text { GARCH } \\
\text { OLS }\end{array}$ & & $\begin{array}{l}0.382 \\
0.386\end{array}$ & $\begin{array}{l}0.451 \\
0.445\end{array}$ & $\begin{array}{l}0.196 \\
0.177\end{array}$ & $\begin{array}{l}-0.058 \\
-0.063\end{array}$ & $\begin{array}{l}-0.282 \\
-0.267\end{array}$ \\
\hline $\begin{array}{l}\text { Industrial metals } \\
\text { GARCH } \\
\text { OLS }\end{array}$ & & $\begin{array}{l}0.285 \\
0.165\end{array}$ & $\begin{array}{l}0.299 \\
0.178\end{array}$ & $\begin{array}{l}0.135 \\
0.079\end{array}$ & $\begin{array}{l}0.001 \\
-0.002\end{array}$ & $\begin{array}{l}-0.146 \\
-0.088\end{array}$ \\
\hline $\begin{array}{l}\text { Precious metals } \\
\text { GARCH } \\
\text { OLS }\end{array}$ & & $\begin{array}{l}0.107 \\
0.150\end{array}$ & $\begin{array}{l}0.076 \\
0.137\end{array}$ & $\begin{array}{l}0.007 \\
0.061\end{array}$ & $\begin{array}{l}-0.111 \\
-0.038\end{array}$ & $\begin{array}{l}-0.139 \\
-0.111\end{array}$ \\
\hline $\begin{array}{l}\text { Agriculture } \\
\text { GARCH } \\
\text { OLS }\end{array}$ & & $\begin{array}{l}0.130 \\
0.108\end{array}$ & $\begin{array}{l}0.116 \\
0.115\end{array}$ & $\begin{array}{l}0.063 \\
0.050\end{array}$ & $\begin{array}{l}0.016 \\
0.006\end{array}$ & $\begin{array}{l}-0.050 \\
-0.047\end{array}$ \\
\hline $\begin{array}{l}\text { Livestock } \\
\text { GARCH } \\
\text { OLS }\end{array}$ & & $\begin{array}{l}0.017 \\
0.014\end{array}$ & $\begin{array}{l}0.052 \\
0.022\end{array}$ & $\begin{array}{l}0.011 \\
0.010\end{array}$ & $\begin{array}{l}0.021 \\
0.003\end{array}$ & $\begin{array}{l}0.013 \\
-0.007\end{array}$ \\
\hline
\end{tabular}

Notes: This table reports the relative improvement of using a hedged portfolio compared to the benchmark of an unhedged portfolio. The unhedged portfolio has a weight of 1 in the energy index. The hedged portfolio has a weight of 1 in the energy index and a weight of $-\mathrm{H}$ in the other asset, where $\mathrm{H}$ is the hedge ratio. The sum of losses measure simply cumulates all the negative returns earned by each portfolio and reports the improvement from the hedged position, while the sum of gains cumulates all positive returns earned by each portfolio. Each measure is defined precisely in section 3 . 


\begin{tabular}{|c|c|c|c|c|c|c|}
\hline \multicolumn{7}{|c|}{ Panel B: Latest subsample — natural gas (2006-2014) } \\
\hline & \multicolumn{4}{|c|}{ Risk measures } & \multicolumn{2}{|c|}{$\begin{array}{l}\text { Return } \\
\text { measures }\end{array}$} \\
\hline Variable & $\begin{array}{l}\text { Nob } \\
\mathrm{S}\end{array}$ & $\begin{array}{l}\text { Varianc } \\
\mathrm{e}\end{array}$ & $\begin{array}{l}\text { Semi- } \\
\text { variance }\end{array}$ & $\begin{array}{l}\text { Sum of } \\
\text { losses }\end{array}$ & Mean & $\begin{array}{l}\text { Sum of } \\
\text { gains }\end{array}$ \\
\hline$\frac{\text { Unhedged }}{\text { benchmark }}$ & 448 & 0.002 & 0.001 & -7.150 & -0.001 & 6.532 \\
\hline $\begin{array}{l}\text { Improvement } \\
\text { relative to } \\
\text { benchmark }(\%)\end{array}$ & & $\begin{array}{l}\text { Varianc } \\
\mathrm{e}\end{array}$ & $\begin{array}{l}\text { Semi- } \\
\text { variance }\end{array}$ & $\begin{array}{l}\text { Sum of } \\
\text { losses }\end{array}$ & Mean & $\begin{array}{l}\text { Sum of } \\
\text { gains }\end{array}$ \\
\hline$\underline{\text { S\&P } 500}$ & & & & & & \\
\hline $\begin{array}{l}\overline{\text { GARCH }} \\
\text { OLS }\end{array}$ & & $\begin{array}{l}-0.087 \\
0.003\end{array}$ & $\begin{array}{l}-0.101 \\
0.007\end{array}$ & $\begin{array}{l}-0.034 \\
-0.003\end{array}$ & $\begin{array}{l}-0.032 \\
-0.013\end{array}$ & $\begin{array}{l}0.020 \\
-0.007\end{array}$ \\
\hline $\begin{array}{l}\text { Oil \& gas equity } \\
\text { GARCH } \\
\text { OLS }\end{array}$ & & $\begin{array}{l}0.060 \\
0.059\end{array}$ & $\begin{array}{l}0.100 \\
0.110\end{array}$ & $\begin{array}{l}0.000 \\
-0.006\end{array}$ & $\begin{array}{l}-0.060 \\
-0.067\end{array}$ & $\begin{array}{l}-0.056 \\
-0.054\end{array}$ \\
\hline $\begin{array}{l}\text { Industrial metals } \\
\text { GARCH } \\
\text { OLS }\end{array}$ & & $\begin{array}{l}-0.009 \\
0.020\end{array}$ & $\begin{array}{l}0.001 \\
0.021\end{array}$ & $\begin{array}{l}0.004 \\
0.005\end{array}$ & $\begin{array}{l}0.021 \\
0.000\end{array}$ & $\begin{array}{l}0.014 \\
-0.007\end{array}$ \\
\hline $\begin{array}{l}\text { Precious metals } \\
\text { GARCH } \\
\text { OLS }\end{array}$ & & $\begin{array}{l}-0.035 \\
0.011\end{array}$ & $\begin{array}{l}-0.047 \\
0.007\end{array}$ & $\begin{array}{l}-0.014 \\
-0.003\end{array}$ & $\begin{array}{l}-0.024 \\
-0.015\end{array}$ & $\begin{array}{l}-0.001 \\
-0.010\end{array}$ \\
\hline $\begin{array}{l}\text { Agriculture } \\
\text { GARCH } \\
\text { OLS }\end{array}$ & & $\begin{array}{l}0.155 \\
0.044\end{array}$ & $\begin{array}{l}0.165 \\
0.053\end{array}$ & $\begin{array}{l}0.073 \\
0.016\end{array}$ & $\begin{array}{l}0.024 \\
0.008\end{array}$ & $\begin{array}{l}-0.047 \\
-0.015\end{array}$ \\
\hline $\begin{array}{l}\text { Livestock } \\
\text { GARCH } \\
\text { OLS }\end{array}$ & & $\begin{array}{l}0.012 \\
0.007\end{array}$ & $\begin{array}{l}0.023 \\
0.014\end{array}$ & $\begin{array}{l}0.012 \\
0.006\end{array}$ & $\begin{array}{l}0.035 \\
0.018\end{array}$ & $\begin{array}{l}0.016 \\
0.007\end{array}$ \\
\hline
\end{tabular}

Notes: This table reports the relative improvement of using a hedged portfolio compared to the benchmark of an unhedged portfolio. The unhedged portfolio has a weight of 1 in the WTI oil index (natural gas index) in Panel A (Panel B). The hedged portfolio has a weight of 1 in the energy index and a weight of $-\mathrm{H}$ in the other asset, where $\mathrm{H}$ is the hedge ratio. The sum of losses measure simply cumulates all the negative returns earned by each portfolio and reports the improvement from the hedged position, while the sum of gains cumulates all positive returns earned by each portfolio. Each measure is defined precisely in section 3 . 


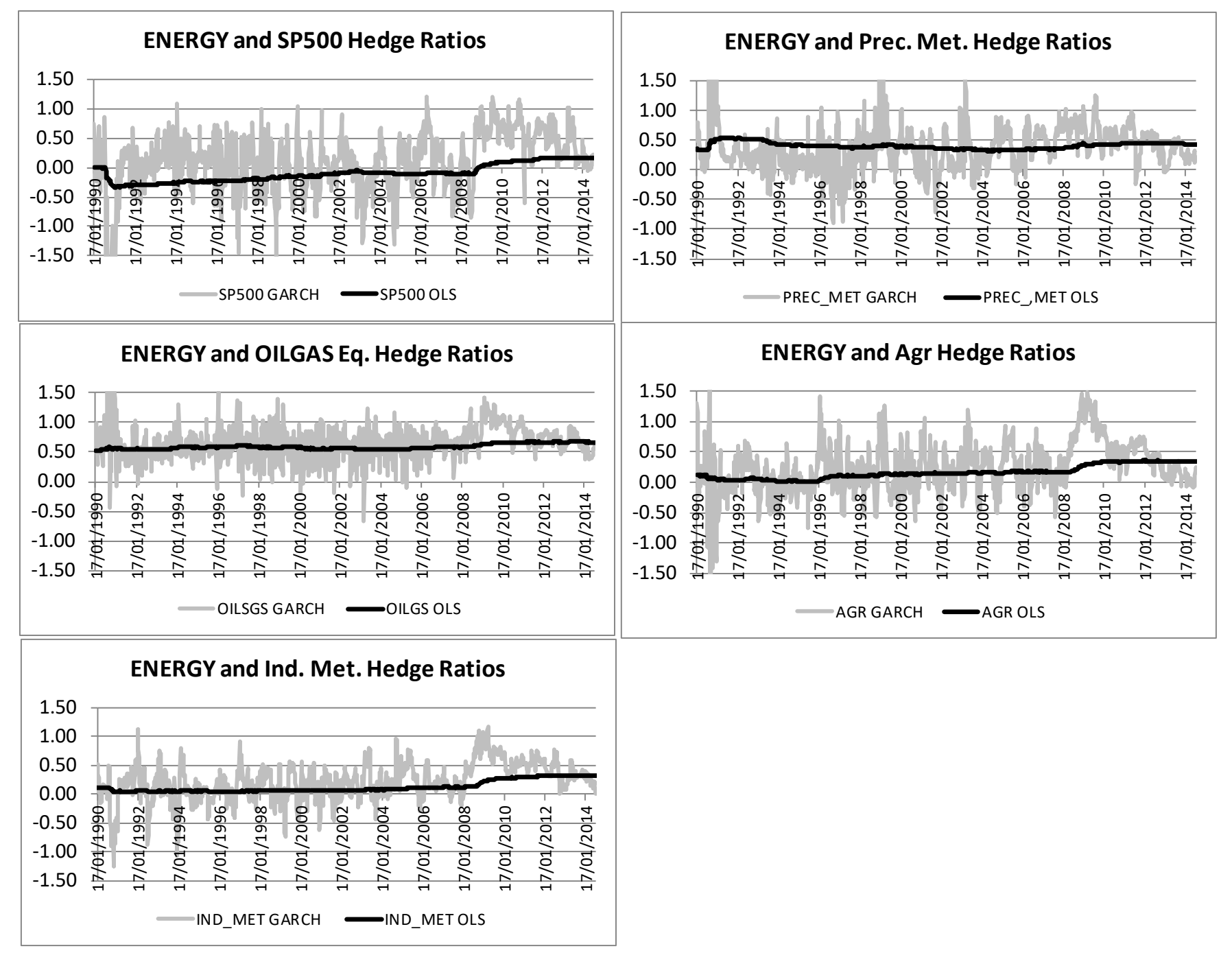

Fig. 1. Time variation in the hedge ratios for each instrument, estimated via a multivariate (BEKK) GARCH model and via OLS.

Notes: All the hedge ratios are estimated recursively over the 1990-2014 period using weekly data. The gray line in Figure 1 shows the estimated hedge ratios using the BEKK GARCH model (equations 1-3 in the manuscript), whereas the black line shows the hedge ratios from a recursive OLS model (equation 5). 


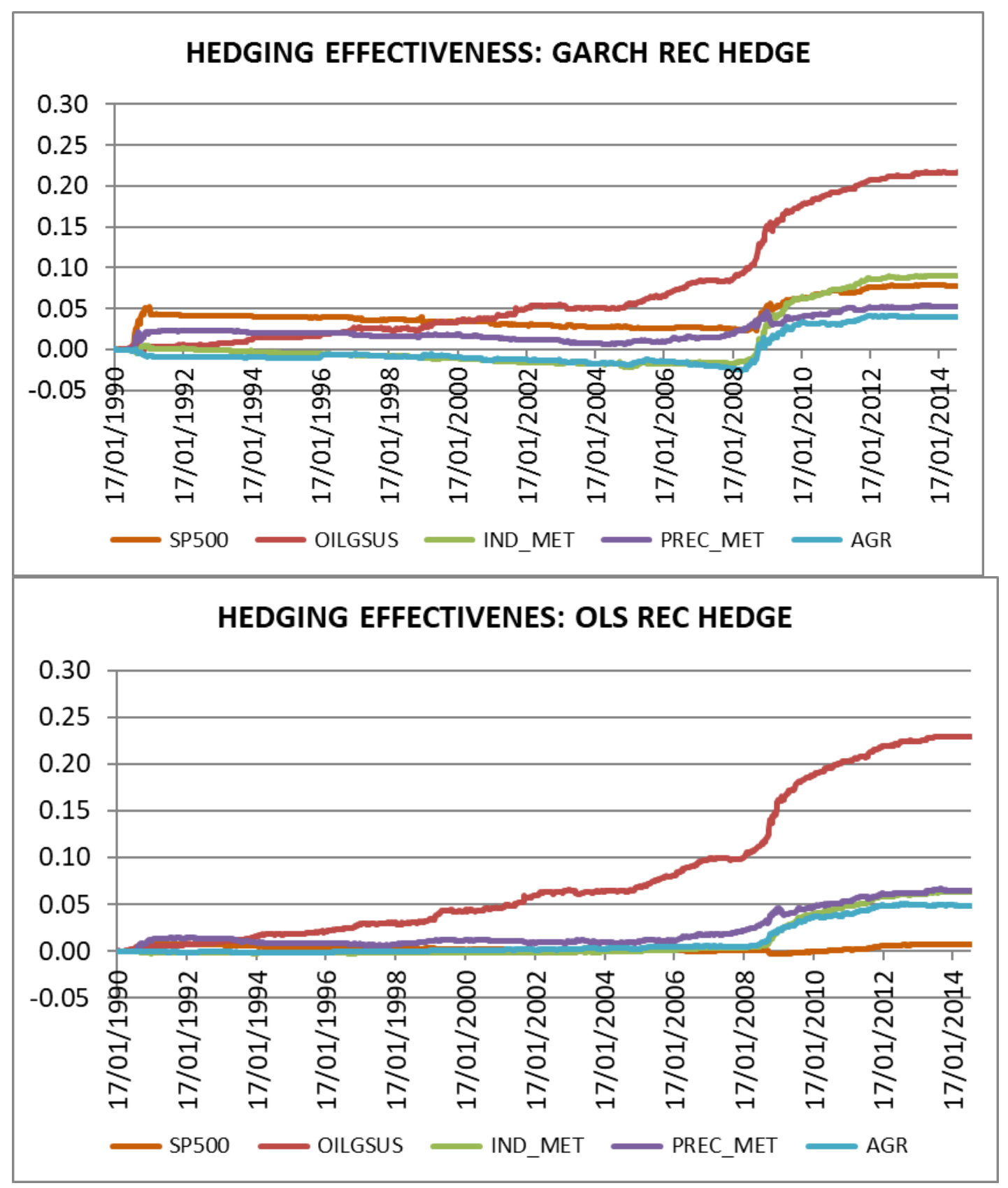

Fig. 2. Hedging effectiveness: measures of reductions in portfolio volatility.

Notes: This figure depicts time variation in the out-of-sample hedging effectiveness of commodities for the energy index using two different methods to estimate the hedge ratio. These are (1) the recursive GARCH method (GARCH REC) and (2) recursive OLS (OLS REC). For GARCH REC and OLS REC a start-up period of 262 observations is used (which then expands as time progresses).

The hedging effectiveness metric calculated in all graphs is $\frac{\sum_{t=1}^{T}\left(R_{U, t}-\bar{R}_{U}\right)^{2}-\sum_{t=1}^{T}\left(R_{H, t}-\bar{R}_{H}\right)^{2}}{\sum_{t=1}^{T}\left(R_{U, t}-\bar{R}_{U}\right)^{2}} \cdot R_{U}$ is the return to the unhedged portfolio,

which has a weight of 1 in the energy index. $R_{H}$ is the return to the hedged portfolio; this has a weight of 1 in the energy index and a weight of $-\mathrm{H}$ in the other asset, where $\mathrm{H}$ is the hedge ratio. This is basically the cumulative reduction in squared return deviations so far to period $\mathrm{t}$, divided by the full sample squared return deviation. A positive value here indicates that the hedge has reduced portfolio variance. An increase in this measure at period $t$ indicates that the hedge reduced variance in period $t$. So in the final graph this tells us that when we use the OLS REC method, the hedge using industrial metals reduces portfolio volatility by over $6 \%$ over the full sample. 

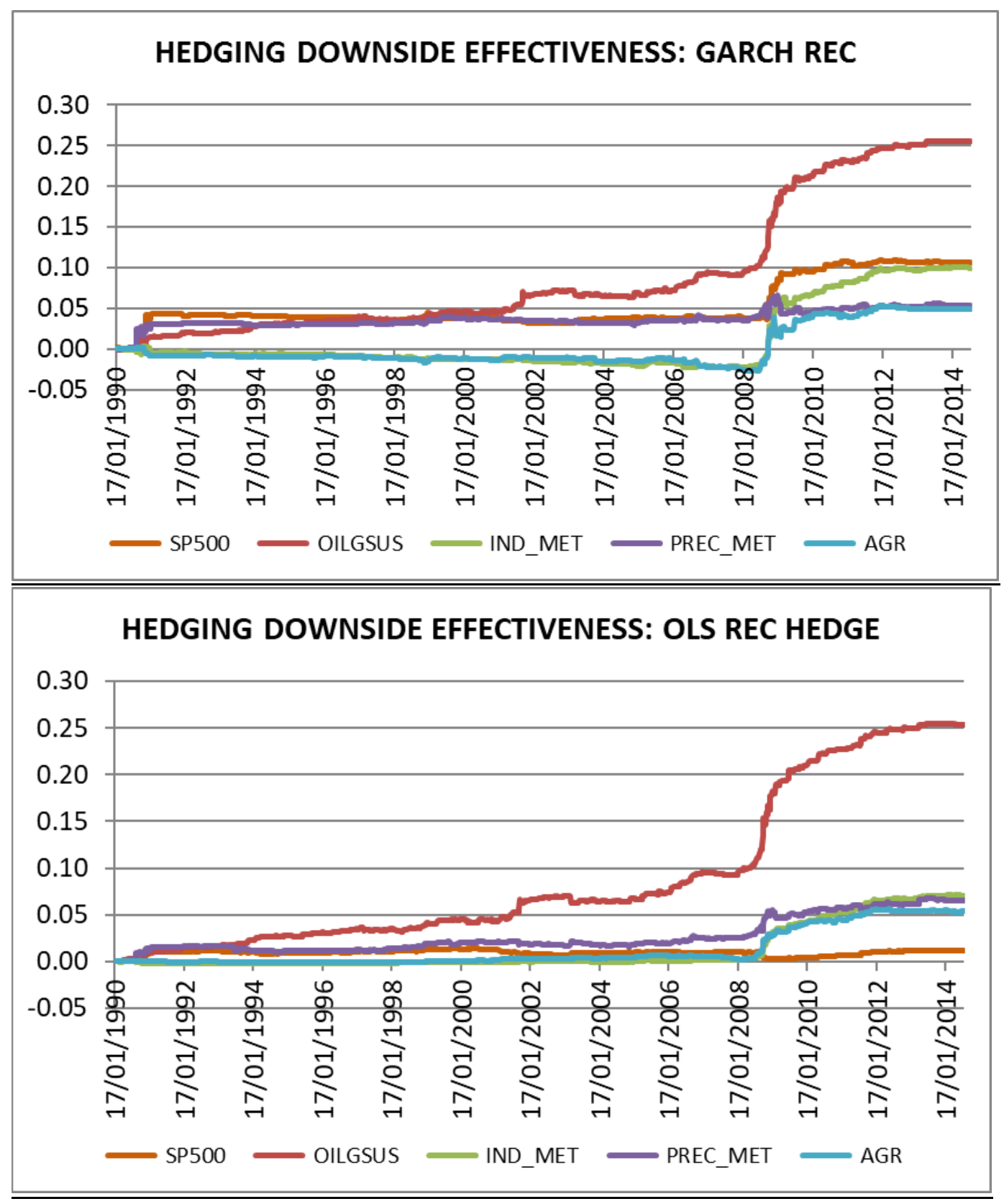

Fig. 3. Hedging downside risk (measures of reductions in semivariance).

Notes: This figure depicts time variation in the out-of-sample ability of a commodities hedge for the energy index, using two different methods to estimate the hedge ratio. These are (1) the recursive GARCH method (GARCH REC) and (2) recursive OLS (OLS REC). For GARCH REC and OLS REC a start-up period of 262 observations is used (which then expands as time progresses).

The semivariance metric calculated in all graphs is $\frac{\sum_{t=1}^{T}\left(R_{U, t}^{B M}-\bar{R}_{U}\right)^{2}-\sum_{t=1}^{T}\left(R_{H, t}^{B M}-\bar{R}_{H}\right)^{2}}{\sum_{t=1}^{T}\left(R_{U, t}^{B M}-\bar{R}_{U}\right)^{2}}$.

$R^{B M}$ is equal to $\mathrm{R}$ when the return is less than or equal to the sample mean and is equal to the sample mean otherwise. $R_{U}$ is the return to the unhedged portfolio, which has a weight of 1 in the energy index. $R_{H}$ is the return to the hedged portfolio; this has a weight of 1 in the energy index and a weight of $-\mathrm{H}$ in the other asset, where $\mathrm{H}$ is the hedge ratio. The semivariance metric is the cumulative reduction in semivariance to period $t$, divided by the full sample semivariance. A positive value here indicates that the hedge has reduced portfolio semivariance. An increase in this measure at period $t$ indicates that the hedge reduced semivariance in period $t$. So in the final graph this tells us that when we use the AV_RT method, the hedge using industrial metals reduces portfolio volatility by over $6 \%$ over the full sample. 

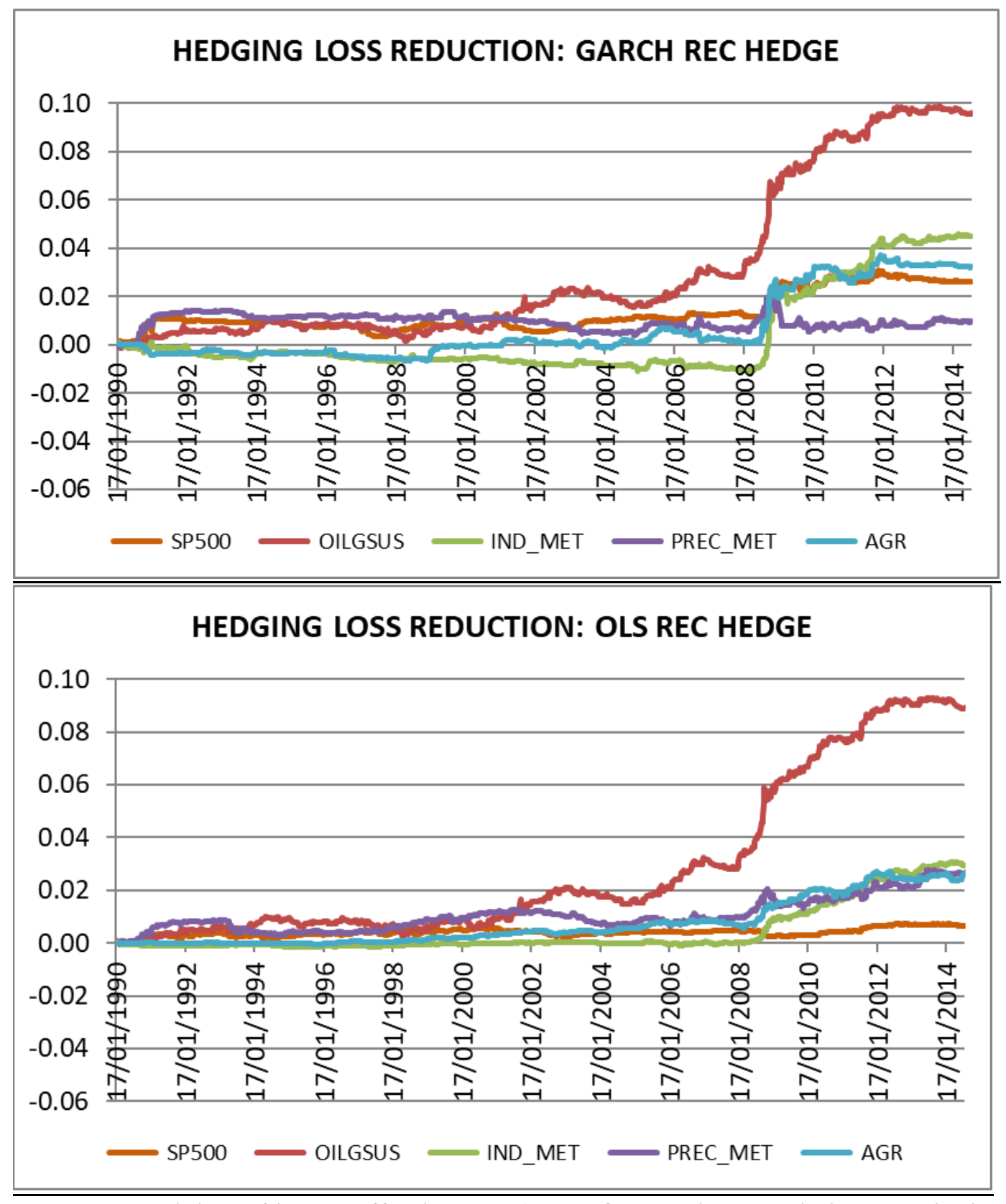

Fig. 4. Hedging of losses effectiveness (sum of return losses relative to unhedged portfolio).

Notes: This figure depicts time variation in the out-of-sample ability of a commodities hedge for the equity index to reduce loss using the energy index, using two different methods to estimate the hedge ratio. These are (1) the recursive GARCH method (GARCH REC) and (2) recursive OLS (OLS REC). For GARCH REC and OLS REC a start-up period of 262 observations is used (which then expands as time progresses).

The sum of losses metric calculated in all graphs is $\frac{\sum_{t=1}^{T} R_{U, t}^{-}-\sum_{t=1}^{T} R_{H, t}^{-}}{\sum_{t=1}^{T} R_{U, t}^{-}} \cdot R_{U, t}^{-}$is the return to the unhedged portfolio, which has a weight of 1 in the energy index, when the portfolio return is negative, and zero otherwise. $R_{H, t}^{-}$is the return to the hedged portfolio when the portfolio return is negative and zero otherwise; the hedged portfolio has a weight of 1 in the energy index and a weight of $-\mathrm{H}$ in the other asset, where $\mathrm{H}$ is the hedge ratio. This is basically the cumulative reduction in losses so far to period t, divided by the full sample sum of losses. A positive value here indicates that the hedge has reduced losses. An increase in this measure at period $t$ indicates that the hedge reduced variance in period $t$. So in the final graph this tells us that when we use the AV RT method, the hedge using industrial metals reduces portfolio losses by about $2 \%$ over the full sample. 


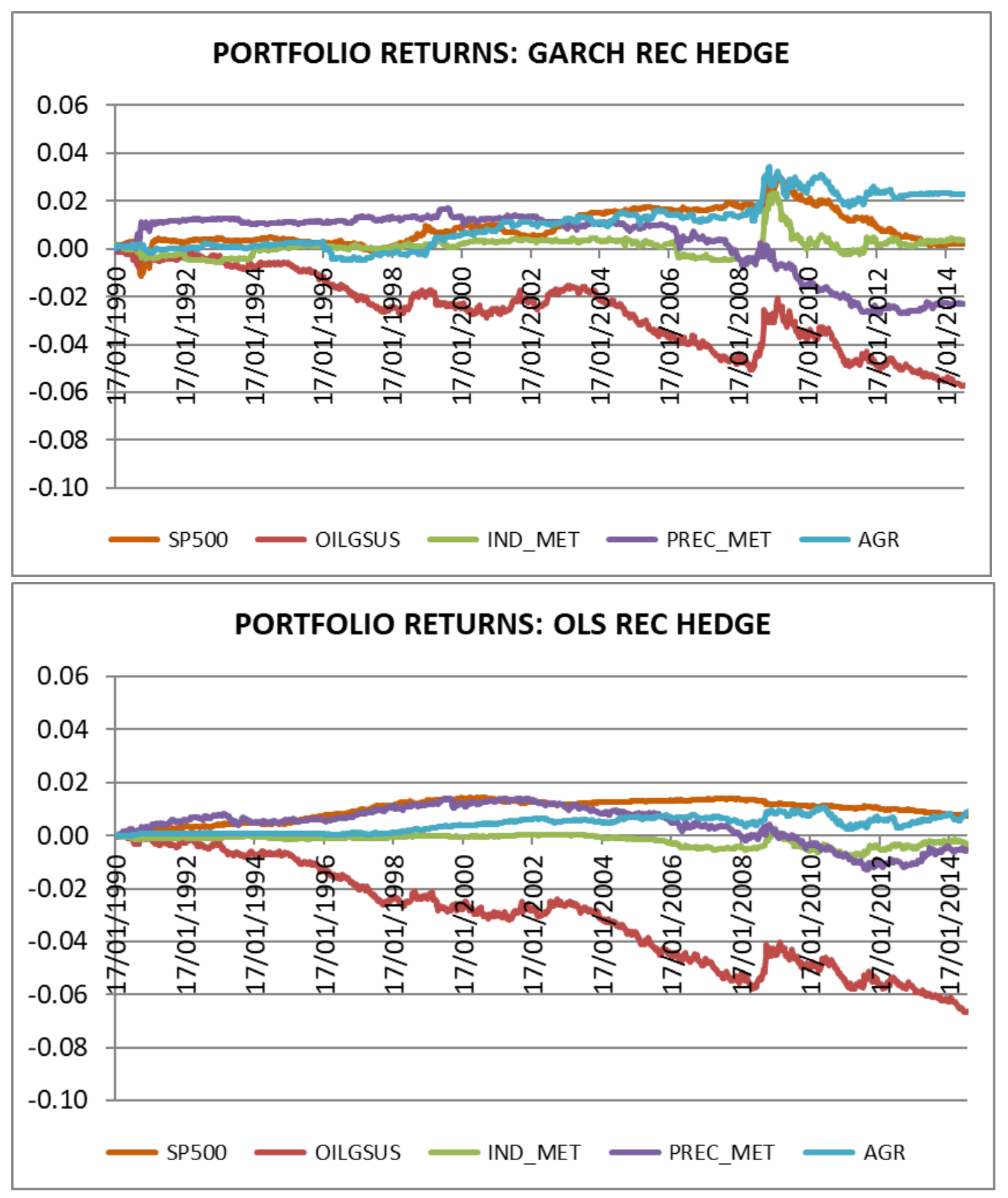

Fig. 5. Impact on portfolio returns.

Notes: This figure depicts time variation in the out-of-sample ability of a commodities hedge for the energy index to increase returns, using two different methods to estimate the hedge ratio. These are (1) the recursive GARCH method (GARCH REC) and (2) recursive OLS (OLS REC). For GARCH REC and OLS REC a start-up period of 262 observations is used (which then expands as time progresses).

The increase in returns metric calculated in all graphs is $52\left(\sum_{t=1}^{T} R_{H, t}-\sum_{t=1}^{T} R_{U, t}\right) \cdot R_{U}$ is the return to the unhedged portfolio, which has a weight of 1 in the energy index. $R_{H}$ is the return to the hedged portfolio; this has a weight of 1 in the energy index and a weight of $-\mathrm{H}$ in the other asset, where $\mathrm{H}$ is the hedge ratio. This is basically the cumulative gain in return so far to period $\mathrm{t}$, divided by the full sample unhedged portfolio return. A positive value here indicates that the hedge has increased portfolio return. An increase in this measure at period t indicates that the hedge increased return in period t. So in the final graph this tells us that when we use the AV_RT method, the hedge using energy increases portfolio return by about $5 \%$ over the full sample. 


\section{Appendix 1.}

Baseline estimation results, full sample.

S\&P 500 (full sample estimates)

\begin{tabular}{|c|c|c|c|}
\hline \multicolumn{4}{|c|}{ Multivariate GARCH model estimates } \\
\hline $\begin{array}{l}\text { Mean model of agriculture } \\
\text { (Prec_MET1) }\end{array}$ & Coefficient & $\begin{array}{l}\text { Std } \\
\text { error }\end{array}$ & P-values \\
\hline Constant & 0.27 & 0.05 & 0.00 \\
\hline SP500 & -0.08 & 0.03 & 0.00 \\
\hline ENERGY $_{\mathrm{t}-1}$ & 0.00 & 0.01 & 0.97 \\
\hline \multicolumn{4}{|l|}{ Mean model of (ENERGY1) } \\
\hline Constant & 0.14 & 0.09 & 0.10 \\
\hline SP500 t-1 & -0.02 & 0.04 & 0.66 \\
\hline ENERGY $_{\mathrm{t}-1}$ & 0.01 & 0.03 & 0.58 \\
\hline \multicolumn{4}{|l|}{ Variance estimates } \\
\hline $\mathrm{C}(1,1)$ & 0.37 & 0.07 & 0.00 \\
\hline $\mathrm{C}(2,1)$ & 0.16 & 0.19 & 0.40 \\
\hline$C(2,2)$ & 0.74 & 0.10 & 0.00 \\
\hline $\mathrm{A}(1,1)$ & 0.32 & 0.03 & 0.00 \\
\hline $\mathrm{A}(1,2)$ & -0.07 & 0.03 & 0.04 \\
\hline $\mathrm{A}(2,1)$ & 0.02 & 0.01 & 0.05 \\
\hline $\mathrm{A}(2,2)$ & 0.34 & 0.02 & 0.00 \\
\hline $\mathrm{B}(1,1)$ & 0.94 & 0.01 & 0.10 \\
\hline $\mathrm{B}(1,2)$ & 0.02 & 0.02 & 0.19 \\
\hline $\mathrm{B}(2,1)$ & -0.01 & 0.01 & 0.09 \\
\hline $\mathrm{B}(2,2)$ & 0.92 & 0.01 & 0.00 \\
\hline \multicolumn{4}{|l|}{ OLS estimates } \\
\hline Observations $=1543$ & $\begin{array}{l}\text { Coefficie } \\
\text { nt }\end{array}$ & Std error & P-values \\
\hline $\mathrm{SP} 500_{\mathrm{t}-1}$ & 0.20 & 0.06 & 0.01 \\
\hline
\end{tabular}

Oil and gas index (full sample estimates)

\begin{tabular}{|c|c|c|c|}
\hline \multicolumn{4}{|c|}{ Multivariate GARCH model estimates } \\
\hline $\begin{array}{l}\text { Mean model of agriculture } \\
\text { (Prec_MET1) }\end{array}$ & Coefficient & $\begin{array}{l}\text { Std } \\
\text { error }\end{array}$ & P-values \\
\hline Constant & 0.33 & 0.06 & 0.59 \\
\hline Oil and gas inde $x_{t-1}$ & -0.09 & 0.03 & 0.00 \\
\hline ENERGY $_{\mathrm{t}-1}$ & 0.04 & 0.02 & 0.00 \\
\hline \multicolumn{4}{|l|}{ Mean model of (ENERGY1) } \\
\hline Constant & 0.11 & 0.09 & 0.82 \\
\hline Oil and gas index $\mathrm{t}_{-1}$ & 0.00 & 0.03 & 0.00 \\
\hline ENERGY $_{\mathrm{t}-1}$ & 0.03 & 0.03 & 0.00 \\
\hline \multicolumn{4}{|l|}{ Variance estimates } \\
\hline $\mathrm{C}(1,1)$ & 0.42 & 0.09 & 0.00 \\
\hline $\mathrm{C}(2,1)$ & 0.10 & 0.08 & 0.00 \\
\hline$C(2,2)$ & -0.67 & 0.08 & 0.99 \\
\hline $\mathrm{A}(1,1)$ & 0.25 & 0.03 & 0.00 \\
\hline $\mathrm{A}(1,2)$ & -0.10 & 0.03 & 0.60 \\
\hline $\mathrm{A}(2,1)$ & 0.00 & 0.02 & 0.00 \\
\hline $\mathrm{A}(2,2)$ & 0.33 & 0.02 & 0.00 \\
\hline $\mathrm{B}(1,1)$ & 0.96 & 0.01 & 0.00 \\
\hline $\mathrm{B}(1,2)$ & 0.05 & 0.02 & 0.87 \\
\hline $\mathrm{B}(2,1)$ & 0.00 & 0.01 & 0.00 \\
\hline $\mathrm{B}(2,2)$ & 0.92 & 0.01 & 0.00 \\
\hline \multicolumn{4}{|l|}{ OLS estimates } \\
\hline Observations $=1543$ & Coefficient & $\begin{array}{l}\text { Std } \\
\text { error }\end{array}$ & P-values \\
\hline Oil and Gas Index $\mathrm{t}_{\mathrm{t}-1}$ & 0.66 & 0.04 & 0.00 \\
\hline
\end{tabular}


Industrial metals (full sample estimates)

\begin{tabular}{|c|c|c|c|c|}
\hline \multicolumn{5}{|c|}{ Multivariate GARCH model estimates } \\
\hline $\begin{array}{l}\text { Mean model of industrial } \\
\text { metals (IND MET1) }\end{array}$ & Coefficient & \multicolumn{2}{|l|}{ Std error } & P-value \\
\hline Constant & 0.00 & 0.06 & & 0.93 \\
\hline IND_MET $_{\mathrm{t}-1}$ & 0.00 & 0.03 & & 0.99 \\
\hline ENERGY $_{\mathrm{t}-1}$ & 0.01 & 0.01 & & 0.43 \\
\hline \multicolumn{5}{|c|}{ Mean model of (ENERGY1) } \\
\hline Constant & 0.11 & 0.09 & & 0.23 \\
\hline IND_MET $_{\mathrm{t}-1}$ & 0.03 & 0.03 & & 0.40 \\
\hline ENERGY $_{\mathrm{t}-1}$ & 0.01 & 0.03 & & 0.63 \\
\hline \multicolumn{5}{|l|}{ Variance estimates } \\
\hline $\mathrm{C}(1,1)$ & 0.37 & 0.03 & & 0.00 \\
\hline $\mathrm{C}(2,1)$ & 0.03 & 0.12 & & 0.79 \\
\hline$C(2,2)$ & 0.75 & 0.08 & & 0.00 \\
\hline $\mathrm{A}(1,1)$ & 0.25 & 0.01 & & 0.00 \\
\hline $\mathrm{A}(1,2)$ & -0.04 & 0.03 & & 0.15 \\
\hline $\mathrm{A}(2,1)$ & 0.02 & 0.01 & & 0.02 \\
\hline $\mathrm{A}(2,2)$ & 0.31 & 0.02 & & 0.00 \\
\hline $\mathrm{B}(1,1)$ & 0.96 & 0.00 & & 0.00 \\
\hline $\mathrm{B}(1,2)$ & 0.01 & 0.01 & & 0.13 \\
\hline $\mathrm{B}(2,1)$ & -0.01 & 0.00 & & 0.09 \\
\hline $\mathrm{B}(2,2)$ & 0.93 & 0.01 & & 0.00 \\
\hline \multicolumn{5}{|l|}{ OLS estimates } \\
\hline Observations $=1543$ & & Coefficient & $\begin{array}{l}\text { Std } \\
\text { error }\end{array}$ & $\begin{array}{l}\text { P- } \\
\text { value }\end{array}$ \\
\hline IND_MET $_{\mathrm{t}-1}$ & & 0.32 & 0.04 & 0.00 \\
\hline
\end{tabular}

Precious metals (full sample estimates)

Multivariate GARCH model estimates

\begin{tabular}{|c|c|c|c|c|}
\hline $\begin{array}{l}\text { Mean model of precious } \\
\text { metals (Prec MET1) }\end{array}$ & Coefficient & Std error & P-valu & des \\
\hline Constant & -0.06 & 0.05 & 0.22 & \\
\hline Prec_MET $T_{\mathrm{t}-1}$ & -0.03 & 0.03 & 0.16 & \\
\hline ENERGY $_{\mathrm{t}-1}$ & 0.01 & 0.01 & 0.45 & \\
\hline \multicolumn{5}{|c|}{ Mean model of (ENERGY1) } \\
\hline Constant & 0.05 & 0.09 & 0.56 & \\
\hline Prec_MET ${ }_{\mathrm{t}-1}$ & -0.05 & 0.04 & 0.17 & \\
\hline ENERGY $_{\mathrm{t}-1}$ & 0.03 & 0.03 & 0.33 & \\
\hline \multicolumn{5}{|l|}{ Variance estimates } \\
\hline $\mathrm{C}(1,1)$ & 0.28 & 0.08 & 0.00 & \\
\hline $\mathrm{C}(2,1)$ & -0.03 & 0.26 & 0.91 & \\
\hline $\mathrm{C}(2,2)$ & 0.89 & 0.10 & 0.00 & \\
\hline $\mathrm{A}(1,1)$ & 0.25 & 0.01 & 0.00 & \\
\hline $\mathrm{A}(1,2)$ & -0.08 & 0.05 & 0.09 & \\
\hline $\mathrm{A}(2,1)$ & 0.04 & 0.01 & 0.00 & \\
\hline $\mathrm{A}(2,2)$ & 0.32 & 0.02 & 0.00 & \\
\hline $\mathrm{B}(1,1)$ & 0.96 & 0.01 & 0.00 & \\
\hline $\mathrm{B}(1,2)$ & 0.04 & 0.02 & 0.02 & \\
\hline $\mathrm{B}(2,1)$ & -0.02 & 0.01 & 0.03 & \\
\hline $\mathrm{B}(2,2)$ & 0.92 & 0.01 & 0.00 & \\
\hline \multicolumn{5}{|l|}{ OLS estimates } \\
\hline Observations $=1543$ & & Coefficient & $\begin{array}{l}\text { Std } \\
\text { error }\end{array}$ & $\begin{array}{l}\mathrm{P}- \\
\text { value }\end{array}$ \\
\hline Prec_MET ${ }_{\mathrm{t}-1}$ & & 0.43 & 0.05 & 0.00 \\
\hline
\end{tabular}


Agriculture (full sample estimates)

\begin{tabular}{|c|c|c|c|}
\hline \multicolumn{4}{|l|}{ Multivariate GARCH model estimates } \\
\hline Mean model of agriculture (Prec_MET1) & Coefficient & $\begin{array}{l}\text { Std } \\
\text { error }\end{array}$ & $\begin{array}{l}\text { P- } \\
\text { valu } \\
\text { es }\end{array}$ \\
\hline Constant & -0.09 & 0.05 & $\begin{array}{l}0.0 \\
9\end{array}$ \\
\hline Agriculture $_{t-1}$ & 0.00 & 0.03 & $\begin{array}{l}0.9 \\
3\end{array}$ \\
\hline ENERGY $_{\mathrm{t}-1}$ & -0.03 & 0.01 & $\begin{array}{l}0.0 \\
1\end{array}$ \\
\hline \multicolumn{4}{|l|}{ Mean model of (ENERGY1) } \\
\hline Constant & 0.13 & 0.09 & $\begin{array}{l}0.1 \\
3\end{array}$ \\
\hline Agriculture $_{t-1}$ & 0.02 & 0.03 & $\begin{array}{l}0.5 \\
8\end{array}$ \\
\hline ENERGY $_{\mathrm{t}-1}$ & 0.02 & 0.02 & $\begin{array}{l}0.5 \\
2 \\
\end{array}$ \\
\hline \multicolumn{4}{|l|}{ Variance estimates } \\
\hline $\mathrm{C}(1,1)$ & 0.34 & 0.06 & $\begin{array}{l}0.0 \\
0\end{array}$ \\
\hline $\mathrm{C}(2,1)$ & -0.55 & 0.12 & $\begin{array}{l}0.0 \\
0\end{array}$ \\
\hline$C(2,2)$ & 0.75 & 0.07 & $\begin{array}{l}0.0 \\
0\end{array}$ \\
\hline $\mathrm{A}(1,1)$ & 0.21 & 0.03 & $\begin{array}{l}0.0 \\
0\end{array}$ \\
\hline $\mathrm{A}(1,2)$ & -0.01 & 0.04 & $\begin{array}{l}0.8 \\
9\end{array}$ \\
\hline $\mathrm{A}(2,1)$ & -0.01 & 0.01 & $\begin{array}{l}0.6 \\
0\end{array}$ \\
\hline $\mathrm{A}(2,2)$ & 0.34 & 0.02 & $\begin{array}{l}0.0 \\
0\end{array}$ \\
\hline $\mathrm{B}(1,1)$ & 0.96 & 0.01 & $\begin{array}{l}0.0 \\
0\end{array}$ \\
\hline $\mathrm{B}(1,2)$ & 0.04 & 0.01 & $\begin{array}{l}0.0 \\
1\end{array}$ \\
\hline $\mathrm{B}(2,1)$ & 0.01 & 0.01 & $\begin{array}{l}0.1 \\
4\end{array}$ \\
\hline
\end{tabular}

$\mathrm{B}(2,2)$

0.91

$0.01 \quad 0.0$

OLS estimates

Observations $=1543$

Coeffici Std error $\mathrm{P}-$

valu

Agriculture $_{t-1}$

$0.34 \quad 0.04$

es

Livestock (full sample estimates)

\begin{tabular}{|c|c|c|c|}
\hline \multicolumn{4}{|l|}{ Multivariate GARCH model estimates } \\
\hline "Mean model of agriculture (Prec_MET1) & Coefficient & $\begin{array}{l}\text { Std } \\
\text { error }\end{array}$ & $\begin{array}{l}\text { P- } \\
\text { valu } \\
\text { es } \\
\end{array}$ \\
\hline Constant & 0.02 & 0.05 & $\begin{array}{l}0.6 \\
5\end{array}$ \\
\hline Livestock $_{\mathrm{t}-1}$ & 0.00 & 0.03 & $\begin{array}{l}0.8 \\
5\end{array}$ \\
\hline ENERGY $\mathrm{t}-1$ & 0.00 & 0.01 & $\begin{array}{l}0.9 \\
6\end{array}$ \\
\hline \multicolumn{4}{|l|}{ Mean model of (ENERGY1) } \\
\hline Constant & 0.14 & 0.09 & $\begin{array}{l}0.1 \\
0\end{array}$ \\
\hline Livestock $_{\mathrm{t}-1}$ & -0.04 & 0.05 & $\begin{array}{l}0.3 \\
6\end{array}$ \\
\hline ENERGY $_{\mathrm{t}-1}$ & 0.02 & 0.03 & $\begin{array}{l}0.4 \\
6 \\
\end{array}$ \\
\hline \multicolumn{4}{|l|}{ Variance estimates } \\
\hline $\mathrm{C}(1,1)$ & 0.29 & 0.05 & $\begin{array}{l}0.0 \\
0\end{array}$ \\
\hline $\mathrm{C}(2,1)$ & -0.02 & 0.27 & 0.9 \\
\hline
\end{tabular}




\begin{tabular}{|c|c|c|c|}
\hline \multirow[b]{2}{*}{$\mathrm{C}(2,2)$} & & \multirow{2}{*}{0.07} & \\
\hline & & & 0.0 \\
\hline $\mathrm{A}(1,1)$ & 0.20 & 0.02 & 0.0 \\
\hline $\mathrm{A}(1,2)$ & 0.11 & 0.06 & $\begin{array}{l}0.0 \\
5\end{array}$ \\
\hline $\mathrm{A}(2,1)$ & 0.00 & 0.01 & $\begin{array}{l}0.8 \\
2\end{array}$ \\
\hline $\mathrm{A}(2,2)$ & 0.32 & 0.02 & $\begin{array}{l}0.0 \\
0\end{array}$ \\
\hline $\mathrm{B}(1,1)$ & 0.97 & 0.01 & $\begin{array}{l}0.0 \\
0\end{array}$ \\
\hline $\mathrm{B}(1,2)$ & -0.03 & 0.03 & $\begin{array}{l}0.3 \\
1\end{array}$ \\
\hline $\mathrm{B}(2,1)$ & 0.01 & 0.01 & $\begin{array}{l}0.3 \\
2\end{array}$ \\
\hline $\mathrm{B}(2,2)$ & 0.93 & 0.00 & $\begin{array}{l}0.0 \\
0\end{array}$ \\
\hline \multicolumn{4}{|l|}{ OLS estimates } \\
\hline 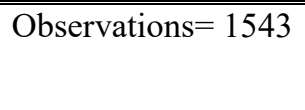 & $\begin{array}{l}\text { Coeffici } \\
\text { ent }\end{array}$ & Std error & $\begin{array}{l}\mathrm{P}- \\
\text { valu } \\
\end{array}$ \\
\hline Livestock $_{\mathrm{t}-1}$ & 0.20 & 0.06 & $\begin{array}{l}0.0 \\
0\end{array}$ \\
\hline
\end{tabular}


Appendix 2.

Baseline descriptive statistics, using full sample without recursive estimation.

\begin{tabular}{lllllllll}
\hline \multicolumn{6}{l}{ Sample statistics } & - hedge ratios with energy \\
\hline Variable & Nobs & Mean & SD & Min & Q1 & Med & Q3 & Max \\
\hline S\&P 500 & & & & & & & & \\
GARCH & 1542 & 0.11 & 0.51 & -2.70 & -0.15 & 0.12 & 0.43 & 1.68 \\
OLS & 1543 & 0.17 & 0.00 & - & - & - & - & - \\
Oil \& gas equity & & & & & & & & \\
GARCH & 1542 & 0.65 & 0.26 & -0.28 & 0.48 & 0.64 & 0.82 & 2.14 \\
OLS & 1543 & 0.66 & 0.00 & - & - & - & - & - \\
Industrial metals & & & & & & & & \\
GARCH & 1542 & 0.26 & 0.31 & -0.83 & 0.05 & 0.21 & 0.44 & 1.36 \\
OLS & 1543 & 0.32 & 0.00 & - & - & - & - & - \\
Precious metals & & & & & & & & \\
GARCH & 1542 & 0.36 & 0.39 & -0.84 & 0.11 & 0.32 & 0.55 & 2.30 \\
OLS & 1543 & 0.43 & 0.00 & - & - & - & - & - \\
Agriculture & & & & & & & & \\
GARCH & 1542 & 0.23 & 0.30 & -0.76 & 0.02 & 0.21 & 0.41 & 1.19 \\
OLS & 1543 & 0.34 & 0.00 & - & - & - & - & - \\
Livestock & & & & & & & & \\
GARCH & 1542 & 0.16 & 0.34 & -1.20 & -0.06 & 0.12 & 0.33 & 2.05 \\
OLS & 1543 & 0.20 & 0.00 & - & - & - & - & - \\
\hline
\end{tabular}

